\title{
Benthic ecosystem functioning in hydrocarbon and heavy-metal contaminated sediments of an Adriatic lagoon
}

\author{
Tamara Cibic $^{1, *}$, Annalisa Franzo ${ }^{1,2}$, Mauro Celussii ${ }^{1}$, Cinzia Fabbro ${ }^{1}$, \\ Paola Del Negro ${ }^{1}$ \\ ${ }^{1}$ Department of Biological Oceanography, OGS (Istituto Nazionale di Oceanografia e Geofisica Sperimentale), \\ 34151 Trieste, Italy \\ ${ }^{2}$ Department of Life Sciences, Università di Trieste, 34127 Trieste, Italy
}

\begin{abstract}
Sediment samples were collected in 4 sites along a salinity gradient (between 0.2 and 27.3) of the Aussa River (Marano Lagoon, northern Adriatic Sea, Italy) and a decreasing gradient of industrial contamination downstream (from Stn A1 to Stn A4) to assess how a riverine-lagoonal system responds to chemical contamination by applying an integrative measure of its benthic ecological properties. Benthic biodiversity (primary producers, meiofauna, macrofauna) along with other structural and functional parameters were related to contamination. Meiofaunal abundance varied between $176 \pm 65$ and $\sim 4000$ ind. $10 \mathrm{~cm}^{-2}$ downstream. The macrofaunal composition shifted from one composed exclusively of chironomid larvae to a typically lagoonal one. At Stn A1, the benthic microalgal abundance exceeded $500000 \mathrm{cells} \mathrm{cm}^{-3}$ and seemed unaffected by contamination. In the freshwater-impacted site, primary production was one order of magnitude higher than in the more saline one $\left(7.20\right.$ and $0.60 \mu \mathrm{g} \mathrm{cm}^{-3} \mathrm{~h}^{-1}$, respectively). High organic carbon

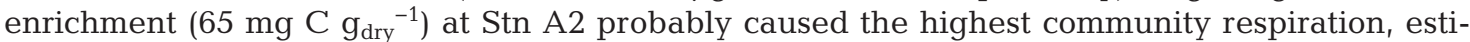
mated by $\mathrm{O}_{2}$ microprofiles, along with the highest exoenzymatic activities ( $\beta$-glucosidase, leucine aminopeptidase and lipase). The 4 investigated sites were well separated by principal component analysis along a decreasing gradient of organic load. An extremely active microbial community in the contaminated site ensured high production and degradation rates. Correct assessment of the benthic ecosystem functioning in polluted areas may represent a useful tool for transitional system management in order to plan environmental interventions in a rational way.
\end{abstract}

KEY WORDS: Lagoonal sediments $\cdot$ Biodiversity $\cdot$ Benthic community $\cdot$ Primary and secondary production $\cdot$ Exoenzymatic activities $\cdot \mathrm{O}_{2}$ microprofiles $\cdot$ Contamination

\section{INTRODUCTION}

Most of the available information on the relationship between biodiversity and benthic ecosystem functioning in coastal lagoons has been historically obtained from studies on macroscopic components. In the last few years there has been a growing interest in the microscopic components of coastal lagoons and their role in the energy transfer to higher trophic levels (Danovaro \& Pusceddu 2007, Pusceddu \& Danovaro 2009). Microbenthic organisms (microalgae, cyanobacteria and heterotrophic prokaryotes) colonise soft bottom sediments in shallow-water areas. These organisms play a major role in biogeochemical processes and drive central ecosystem functions, such as primary production (PP), decomposition and nutrient recycling (Larson \& Sundbäck 2008). 
Despite their biological sensitivity, the north Adriatic coastal lagoons host vast human populations with their associated anthropogenic impacts. The human-derived pressures are diverse and result from many activities such as agriculture, industry, urban development, nautical activities, and sediment dredging. Contaminated systems are in general exposed simultaneously to combined stress factors, including (1) a suite of chemical contaminants (e.g. metals, petroleum hydrocarbons, insecticides and/or herbicides), (2) organic enrichment (and oxygen depletion) and (3) elevated nutrient levels. Each stressor can uniquely affect species within a community and may produce synergistic effects when combined. Multiple-stressor impacts may be relatively unpredictable at a community level (Fleeger et al. 2003). Laboratory studies are seldom able to predict long-term ecological effects of severe contamination by different chemical compounds, especially with regard to functional interactions among organisms and between trophic levels (Carman et al. 1995). Predators and prey are exposed simultaneously to toxicants in the field. The direct influence of contaminants on predators can lead to cascading indirect effects on resistant species in other trophic levels. Resource availability may be likewise influenced by contaminants, which may in turn modify important ecosystem functions (e.g. decomposition rates, oxygen dynamics and nutrient recycling) (Fleeger et al. 2003).

Aquatic ecosystems adapt and respond to pollution at several different levels (system, community and organism). On heavily polluted sediments, microbial communities resistant to specific pollutants or to a synergistic effect of several contaminants may frequently develop (Nogales et al. 2011). The benthic ecosystem adapts to human pressure, minimising its impact through the development of these stressresistant communities that occupy new ecological niches. Therefore, a highly specialised food web that allows the benthic ecosystem to reach a state of equilibrium can thus be established.

Many studies report changes in abundance or diversity of microbial communities (in the broad sense) in chronically polluted marine environments. Other fundamental aspects, such as how pollution affects primary and secondary production, respiration rates or other microbial processes have not yet been analysed in chemically polluted environments. There is also a need for relating changes in diversity to metabolic processes, which are important for the functioning of the ecosystem (Nogales et al. 2011).
Few surveys have been carried out in the GradoMarano lagoonal system (northern Adriatic Sea, Italy). They focused mainly on recent mercury contamination in the bottom sediments (Piani et al. 2005, Covelli et al. 2009). Biological studies have encompassed the distribution of picoplanktonic cyanobacteria (Paoli et al. 2007), phytoplankton (Facca \& Sfriso 2009), microphytobenthos (MPB) (Sdrigotti \& Welker 2002, Blasutto et al. 2005) and macroalgae (Falace et al. 2009). Higher heterotrophic levels have also been considered (Sconfietti \& Marchini 2001, Dondi et al. 2003). However, with the exception of a few PP measurements (Blasutto et al. 2005), no other functional parameters (respiration, secondary production, degradation) have been estimated in this lagoonal system.

Despite a growing awareness and an increasing number of laboratory studies considering multiple stressors, the cumulative effects of co-occurring stressors in natural lagoonal communities remain largely unknown. The aim of the present study was to assess how a riverine-lagoonal system responds to chemical contamination by applying an integrative measure of its benthic ecological properties. We sought to answer the following questions in our study: (1) How do the biodiversity and the functioning of a riverine-lagoonal benthic ecosystem vary along a contamination gradient? (2) Is a contaminated site necessarily a low-diversity benthic system at all trophic levels? (3) What role do microbial communities play in the functioning of a heavily contaminated benthic ecosystem?

\section{MATERIALS AND METHODS}

\section{Study site}

With an average width of $5 \mathrm{~km}$ and extending for about $35 \mathrm{~km}$, the Grado-Marano wetland system covers an area of $160 \mathrm{~km}^{2}$ (Fig. 1). It is located along the northern Adriatic coast between the Tagliamento and Isonzo river deltas. The lagoon is characterised by semi-diurnal tidal fluxes $(65 \mathrm{~cm}$ and $105 \mathrm{~cm}$ mean and spring tidal range, respectively). Salinity values are very low ( 2 to 7 ) in the areas close to the river mouths. They increase towards the tidal inlets, where values between 24 and 36 have been recorded (Brambati 2001). Freshwater inputs are very scarce and mostly limited to the western sector (Marano Lagoon). The overall amount of average freshwater discharge has been estimated to be about 70 to $80 \mathrm{~m}^{3} \mathrm{~s}^{-1}$, with a maximum peak of $100 \mathrm{~m}^{3} \mathrm{~s}^{-1}$ (Mosetti 


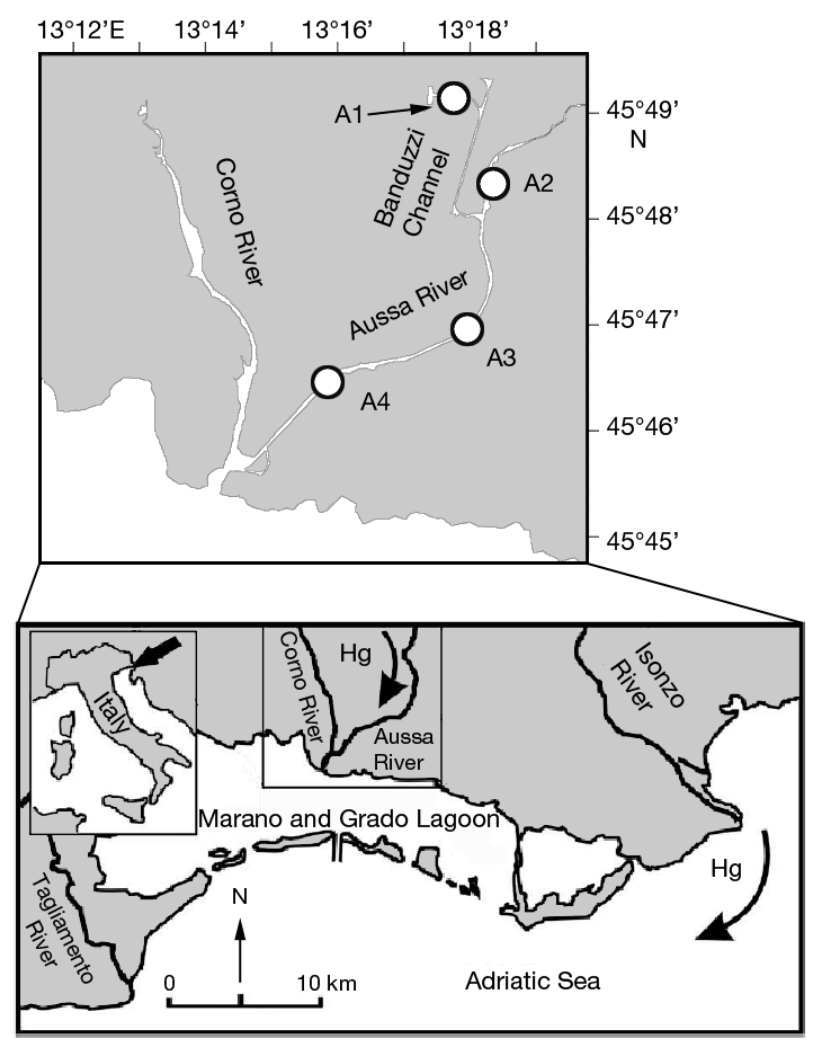

Fig. 1. Study sites in the Banduzzi Channel (Stn A1) and along the Aussa River (Stns A2 to A4) in the Grado-Marano lagoonal system. Modified after Covelli et al. (2009)

1983). The Aussa and Corno rivers originate from the spring line area located in the southern part of the coastal plain, and flow into the central sector of the lagoon $\left(45 \mathrm{~km}^{2}\right)$. The Corno River, which has a total length of $17 \mathrm{~km}$, drains a basin of about 5000 ha and receives few tributaries, hence its limited degree of discharge $\left(5\right.$ to $\left.8 \mathrm{~m}^{3} \mathrm{~s}^{-1}\right)$. In contrast, the Aussa River has several tributaries, drainage channels and irrigation ditches and its total discharge reaches 8 to $20 \mathrm{~m}^{3} \mathrm{~s}^{-1}$. Maximum/minimum discharges occur in October/February and December/September for the Corno and Aussa rivers, respectively. During dry periods, thermo-haline stratification occurs and the presence of a net salt-wedge tip can be detected. In addition, downflowing is often hindered when particular weather conditions or high tides occur (Covelli et al. 2009). The highest contents of fine silt occur where the Zellina and Aussa-Corno rivers enter the lagoon. The ratio of fine silt ( 2 to $16 \mu \mathrm{m})$ to clay $(<2 \mu \mathrm{m})$ identifies areas affected by freshwater inputs into the lagoon: a high ratio indicates an area of fresh water input and vice versa (Brambati 1997). Due to the substantial human impact caused by urban settlements and industrial activities, this area of the lagoon is highly vulnerable. Porto Nogaro, located $1 \mathrm{~km}$ north of the Aussa-Corno mouth, is the most important industrial site in the region. In addition, the Torviscosa industrial complex produced cellulose from cane (Arundo donax) from the 1940s to 1992. It is estimated that about $20 \mathrm{~kg} \mathrm{~d}^{-1}$ of $\mathrm{Hg}$ was discharged into the Aussa River since 1949 (when the chlor-alkali plant became operative). Soda production was increased from 4500 tons in 1950 to 20000 tons during the following $10 \mathrm{yr}$. In 1970 the amount of discharged $\mathrm{Hg}$ decreased to $6-7 \mathrm{~kg} \mathrm{~d}^{-1}$. Then it presumably stopped in 1984 when wastewater treatment systems were installed. At present, industrial effluents flow through submarine pipes that discharge processing effluent into the open sea (about $6.5 \mathrm{~km}$ offshore from the main tidal inlet). An estimated total amount of $186000 \mathrm{~kg}$ of $\mathrm{Hg}$ was released into the river and a significant volume of this $\mathrm{Hg}$ probably reached the lagoon environment. This site is currently under intense investigation, and some corrective actions (e.g. soil removal and groundwater treatment) are in progress (Piani et al. 2005 and references therein). In August 2009 the Special Commissioner for the socio-economic and environmental emergency in the Lagoon of Marano Lagunare and Grado ordered measurements of several contaminants. Up to 75 different points were sampled within the Banduzzi Channel. Concentrations are summarised in Table 1.

\section{Sampling}

Samples were collected in December 2010 and January 2011. Sampling was performed by boat at 3 different stations along the main axis of the AussaCorno River system (Fig. 1) and one located within the Banduzzi Channel during spring ebb-tide conditions (tidal range: 55 to $56 \mathrm{~cm}$ ). Bottom water samples were collected by means of a 21 horizontal Niskin bottle. At the moment of sampling, photosynthetically active radiation (PAR) and water temperature were recorded in situ by a Profiling Natural Fluorometer PNF-300 (Biospherical Instruments). Salinity was measured from bottle-collected water by means of a conductivity meter (WTV LF196). At each station, 5 virtually undisturbed sediment cores were taken by SCUBA divers using polycarbonate sample tubes $(12.7 \mathrm{~cm}$ inner diameter [i.d.] with a sample area of $\left.127 \mathrm{~cm}^{2}\right) ; 1$ sediment core was used for meiofauna sampling, and 1 for oxygen microprofiling. From the 3 remaining cores, 3 sediment layers 
Table 1. Contaminants measured in surface sediments within the Banduzzi Channel. Concentrations of heavy metals are expressed in $\mathrm{mg} \mathrm{kg}^{-1}$; methylmercury and all other contaminants in $\mu \mathrm{g} \mathrm{kg}^{-1}$ (sediment dry mass). LD: detection limit; TP: total phosphorus; PCBs: polychlorobiphenyls; PAHs: polycyclic aromatic hydrocarbons; DDTs: dichlorodiphenyltrichloroethanes; PCDFs: polychlorodibenzofurans; PCDDs: polychlorodibenzo-p-dioxins

\begin{tabular}{|c|c|c|c|}
\hline Contaminant & Min. & Max. & $\begin{array}{c}\text { No. of } \\
\text { samples }\end{array}$ \\
\hline As & $<0.1$ & 9.2 & 75 \\
\hline $\mathrm{Cd}$ & $<0.1$ & 1.2 & 75 \\
\hline Total Cr & 7.5 & 110 & 75 \\
\hline Cr (VI) & $<0.5$ & $<0.5$ & 10 \\
\hline $\mathrm{Cu}$ & 3.6 & 150 & 75 \\
\hline $\mathrm{Hg}$ & $<0.06$ & 1529 & 75 \\
\hline Methylmercury & 0.02 & 59.5 & 10 \\
\hline $\mathrm{Ni}$ & 3.2 & 110 & 75 \\
\hline $\mathrm{Pb}$ & 1.7 & 100 & 75 \\
\hline $\mathrm{Se}$ & $<0.1$ & 3.7 & 39 \\
\hline Va & 11 & 94 & 39 \\
\hline $\mathrm{Zn}$ & 10 & 150 & 75 \\
\hline $\mathrm{TP}$ & 93 & 2000 & 75 \\
\hline Heavy hydrocarbons (C > 12) & 10 & 1220 & 39 \\
\hline Hexachlorobenzene & $<\mathrm{LD}$ & 820 & 39 \\
\hline Total PCBs & $<\mathrm{LD}$ & 5500 & 29 \\
\hline Total PAHs & 2.7 & 37000 & 39 \\
\hline Total DDTs & $<\mathrm{LD}$ & 95 & 39 \\
\hline Monobutyltin & $<0.1$ & 4.6 & 10 \\
\hline Dibutyltin & $<0.1$ & 0.1 & 10 \\
\hline Tributyltin & $<0.1$ & 0.1 & 10 \\
\hline PCDFs & 0.004 & 108.5 & 10 \\
\hline PCDDs & 0.02 & 11 & 10 \\
\hline
\end{tabular}

(ca. 0-2, 2-4 and 4-6 cm) were sampled and each layer homogenised. Additional sediment samples were collected using a stainless steel Van Veen grab (sampling area: $0.06 \mathrm{~m}^{2}$ ).

\section{Granulometry, total organic carbon and chl a}

For each layer of each station, aliquots (10 to $15 \mathrm{~g}$ ) of homogenised sediment were collected for grainsize analysis and processed as described by Cibic et al. (2007a). The analyses were performed using a Malvern Multisizer 2000S. Data are expressed as percentage of sand, silt and clay. For total organic carbon (TOC) analyses, triplicate subsamples of homogenised sediment $(<250 \mu \mathrm{m})$ were weighed directly in a capsule $(5 \times 9 \mathrm{~mm})$, treated with increasing concentrations of $\mathrm{HCl}(0.1 \mathrm{~N}$ and $1 \mathrm{~N})$ to remove carbonates (Nieuwenhuize et al. 1994) and assessed according to the methods of Pella \& Colombo (1973) and Sharp (1974). Pigments were extracted overnight $\left(4^{\circ} \mathrm{C}, 90 \%\right.$ acetone) from 0.7 to $0.9 \mathrm{~g}$ of wet sediment and spectrofluorometrically analysed following the procedures described by Lorenzen \& Jeffrey (1980).

\section{Labile organic matter}

Subsamples of homogenised sediment were freeze-dried and processed for the determination of carbohydrates, lipids and proteins. Colloidal and EDTA-extractable carbohydrates were analysed following the method described by Blasutto et al. (2005). Lipids were analysed following the method proposed by Bligh \& Dyer (1959) and modified for sediments. Proteins were extracted in $\mathrm{NaOH}$ (0.5 M) for $4 \mathrm{~h}$ and determined according to the methods in Hartree (1972). All analyses were carried out in 4 replicates. Carbohydrate, lipid and protein concentrations were converted to carbon equivalents (Fichez 1991). The sum of carbohydrates, lipids and proteins was referred to as labile organic matter (LOM).

\section{Benthic prokaryotes}

Three aliquots of sediment $\left(0.5 \mathrm{~g}_{\text {wet }}\right)$ were withdrawn from each sediment sample, transferred into sterile test tubes and fixed with $3 \mathrm{ml}$ of pre-filtered ( $0.2 \mu \mathrm{m}$ pore size) and buffered formaldehyde solution $(3 \% \mathrm{v} / \mathrm{v}$ final concentration in autoclaved seawater). The sediment slurry was kept at $4^{\circ} \mathrm{C}$ for $24 \mathrm{~h}$, then washed twice with $3 \mathrm{ml}$ of $1 \times$ phosphatebuffered saline (PBS) (pH: 7.2) by centrifuging at $500 \times g$ to remove the supernatant, and stored in $1 \times$ PBS-ethanol (1:1) at $-20^{\circ} \mathrm{C}$ (Ravenschlag et al. 2000). For the subsequent sample processing, a modified protocol by Lunau et al. (2005) was followed: $100 \mu \mathrm{l}$ of sediment slurry was diluted with $900 \mu \mathrm{l}$ sterilised Milli-Q water and $100 \mu \mathrm{l}$ methanol. The diluted samples were placed in a water bath at $35^{\circ} \mathrm{C}$ for $15 \mathrm{~min}$, sonicated in ice (3 times for $1 \mathrm{~min}$ with 2 breaks of $30 \mathrm{~s}$ in between), diluted again with sterile Milli-Q water to a final concentration of 1:110 and filtered on black Nuclepore polycarbonate $0.2 \mu \mathrm{m}$ pore-size filters. Filters were mounted on microscope slides, stained with a SYBR Green Imounting medium Mowiol solution (1:15) and counted by epifluorescence microscopy at $1000 \times$ magnification (Leica DM2500). A minimum of 300 cells were counted for each filter in at least 20 randomly selected fields under a blue filter set (excitation: 450 to $490 \mathrm{~nm}$; barrier: $515 \mathrm{~nm}$ ). 


\section{Enumeration of functional bacterial groups}

The standard 5-tube most-probable-number (MPN) method (Alexander 1982) was adopted to estimate the abundance of functional bacterial groups. Subsamples of homogenised sediment $\left(\sim 5 \mathrm{~g}_{\text {wet }}\right)$ were placed in sterile tubes with $45 \mathrm{ml}$ of pre-filtered bottom water $(0.2 \mu \mathrm{m}$ filters $)$, stirred, sonicated and centrifuged at $956 \times g$ for $1 \mathrm{~min}$ to remove sediment particles. Supernatant and 5 serial 10 -fold diluted inoculums were added to the wells containing specific medium $(10 \% \mathrm{v} / \mathrm{v})$ and incubated at $20^{\circ} \mathrm{C}$. Cellulose-degrading bacteria were estimated using a medium enriched with nitrates and calcium carbonate in which pure cellulose strips were the only source of carbon; tubes in which the cellulose strip decomposed after 1 mo of incubation were considered as positives (MPAAF 2002). Alkane- and petroleum-degrading bacteria were enumerated by adding $\mathrm{n}$-hexadecane $\left(\mathrm{C}_{16}\right)(3.4 \% \mathrm{v} / \mathrm{v})$ and unleaded petrol $(3.4 \% \mathrm{v} / \mathrm{v})$ to $\mathrm{BH}$ medium (Bushnell \& Haas 1941). Hydrocarbon degradation was detected after $15 \mathrm{~d}$ by adding a solution of 2-(4-iodophenyl)-3-(4nitrophenyl)-5-phenyl-2H-tetrazolium $\left(0.6 \mathrm{~g} \mathrm{l}^{-1}\right.$ final concentration) and the appearance of a red-violet colour after $24 \mathrm{~h}$ incubation was considered as a positive reaction (Johnsen et al. 2002).

\section{MPB}

For MPB analyses, aliquots of $2 \mathrm{~cm}^{3}$ of each homogenised sediment layer were processed and counted following the protocol described by Cibic et al. $(2007 \mathrm{a}, \mathrm{b})$; qualitative identification was carried out using the flora cited therein as well as the identification keys of freshwater microalgae by Lund \& Lund (1995). The microalgal taxonomy was based on Round et al. (1992). Three replicates were counted for the uppermost layer at each station and only one replicate was counted for the subsurface layers.

\section{Meiofauna}

From a virtually undisturbed sediment core, 3 replicates were gently taken using cut-off plastic syringes $(2.7 \mathrm{~cm}$ i.d., length: $11.4 \mathrm{~cm})$ and immediately frozen at $-20^{\circ} \mathrm{C}$ (Higgins \& Thiel 1988). While sediment cores for the other parameters were sectioned in 3 layers (ca. $0-2,2-4$ and $4-6 \mathrm{~cm}$ ), the top $10 \mathrm{~cm}$ of the sediment core was considered for meiofauna. Subsamples were preserved in buffered
$4 \%$ formaldehyde solution using pre-filtered seawater, and stained with Rose Bengal $\left(0.5 \mathrm{~g} \mathrm{l}^{-1}\right)$. Sediment samples were sieved through 1000 and $38 \mu \mathrm{m}$ mesh nets, and organisms (from the sediment retained on the $38 \mu \mathrm{m}$ sieve) were extracted by centrifuging the samples 3 times $(1932 \times g, 10 \mathrm{~min})$ with Ludox AM-30 (density: 1.15 to $1.18 \mathrm{~g} \mathrm{~cm}^{-3}$ ) as described by Danovaro et al. (2004). All meiobenthic animals were counted and taxonomically classified into the main groups according to Higgins \& Thiel (1988) under a stereomicroscope (Olympus SZX12; final magnification of 40 or $80 \times$ ). The abundance was expressed as number of individuals per $10 \mathrm{~cm}^{2}$.

\section{Macrofauna}

Macrobenthos were sampled with a Van Veen grab; 3 replicates per station were taken, sieved through a $1000 \mu \mathrm{m}$ sieve and immediately frozen at $-20^{\circ} \mathrm{C}$. After defrosting and sorting, animals were counted and identified to the lowest possible taxonomical level using a stereomicroscope at 7 to $40 \times$ magnification (Rees et al. 1990). For the identification of organisms, the taxonomical keys listed in Morri et al. (2004) were used. The abundance was expressed as number of individuals per $\mathrm{m}^{2}$.

\section{PP of MPB}

PP was estimated in the laboratory from ${ }^{14} \mathrm{C}$ incubation of slurries. Ten $\mathrm{cm}^{3}$ of homogenised surface sediment were drawn off from the slurries, resuspended in $190 \mathrm{ml}$ of overlying filtered seawater $(0.2 \mu \mathrm{m}$ filter $)$ and inoculated with $20 \mu \mathrm{Ci}(0.74 \mathrm{MBq})$ of $\mathrm{NaH}^{14} \mathrm{CO}_{3}$ (DHI, Denmark) (Steemann-Nielsen 1952). After stirring, the slurry was transferred into 21 glass vials containing $9 \mathrm{ml}$ which were divided as follows: 3 replicates to assess the sediment matrix effect, 3 dark replicates, and 3 replicates for each of 5 light intensities. Samples were incubated in a thermostatic chamber at in situ temperature under a gradient of light intensities $(20,30,50,100,200 \mu \mathrm{mol}$ photons $\mathrm{m}^{-2} \mathrm{~s}^{-1}$ ) and after $45 \mathrm{~min}$, carbon incorporation was stopped by adding $200 \mu \mathrm{l}$ of $5 \mathrm{~N} \mathrm{HCl}$ (final $\mathrm{HCl}$ concentration: $0.11 \mathrm{~N}$ ) (Cibic \& Virgilio 2010). Subsequently, samples were treated as described in detail by Cibic et al. (2008). $\mathrm{PP}_{\mathrm{s}}$ refers to data obtained at in situ light conditions, whereas $\mathrm{PP}_{\mathrm{p}}$ refers to the potential PP, i.e. the highest value obtained under a gradient of light intensities. 


\section{$\mathrm{O}_{2}$ consumption rates}

Intact sediment cores for $\mathrm{O}_{2}$ consumption estimates in darkness were sampled and transferred to a cryostatic system to maintain the in situ temperature. A stable water flow above the sediment surface was established by a pressure-regulating air pump that maintained a diffusive boundary layer of 300 to $500 \mu \mathrm{m}$ and kept the overlying water at atmospheric oxygen saturation at all times. Steady-state $\mathrm{O}_{2}$ microprofiles were measured using Clark-type $\mathrm{O}_{2}$ microelectrodes with a guard cathode (Revsbech 1989) with external tip diameter $<100 \mu \mathrm{m}$, stirring sensitivity $<2 \%$, and a $90 \%$ response time $<8$ s. The sensor current was measured using a Unisense PA2000 picoammeter. Data were recorded with Unisense Profix software version 3.10. A step size of $100 \mu \mathrm{m}$ was used. For the interpretation of the measured $\mathrm{O}_{2}$ concentration profiles, the software PROFILE version 1.0 (Berg et al. 1998) was used. Areal rates of oxygen respiration were calculated as described by Cibic et al. (2007b).

\section{Degradative activities}

Extracellular enzymatic activities were assayed using fluorogenic substrata analogues (Hoppe 1993) derived from 7-amino-4-methyl-coumarin (AMC) and 4-methyl-umbelliferone (MUF). Leucine aminopeptidase activity was assayed as the hydrolysis rate of leucine-AMC. $\alpha$-glucosidase, $\beta$-glucosidase, lipase and alkaline phosphatase were assayed using MUF$\alpha$-D-glucoside, MUF- $\beta$-D-glucoside, MUF-oleate, and MUF-phosphate, respectively. Enzyme activities were expressed in terms of the rate of MUF or AMC production. Sediment slurries were prepared by adding $6 \mathrm{ml}$ of $0.2 \mu \mathrm{m}$-filtered bottom water to $0.5 \mathrm{~g}$ of wet sediment. After evaluating the saturating concentrations, hydrolysis rates were measured by incubating slurries with (final concentrations): $800 \mu \mathrm{M}$ leucineAMC, $400 \mu \mathrm{M}$ MUF- $\alpha$-D-glucoside, MUF- $\beta$-D-glucoside, MUF-oleate and $50 \mu \mathrm{M}$ MUF-phosphate for $1 \mathrm{~h}$ in the dark at in situ temperature. Before spectrofluorometric measurements, each sample was centrifuged for $2 \mathrm{~min}$ at $956 \times g$. Fluorescence increase due to MUF and AMC hydrolysed from the model substrates was measured using a Shimadtzu RF-1501 spectrofluorometer (MUF: $365 \mathrm{~nm}$ excitation and $455 \mathrm{~nm}$ emission; AMC: $380 \mathrm{~nm}$ excitation and $440 \mathrm{~nm}$ emission). Standard solutions of MUF and AMC were used to produce calibration curves with $0.2 \mu \mathrm{m}$-filtered bottom water. Triplicate blanks with- out fluorogenic substrata were used to determine the natural fluorescence increase in the samples that was not attributable to the tested enzymes.

\section{Prokaryotic carbon production}

Prokaryotic carbon production (PCP) estimates in sediment samples were carried out by the method of Van Duyl \& Kop (1994), as detailed by Manini et al. (2004). Each sediment sample $(0.2 \mathrm{ml}$ of $1: 1 \mathrm{v} / \mathrm{v}$ slurry) was added to $6 \mu \mathrm{Ci}$ of ${ }^{3} \mathrm{H}$-leucine and incubated in the dark for $1 \mathrm{~h}$ at in situ temperature. After incubation, radiotracer incorporation was stopped by adding $80 \%$ ethanol $(1.7 \mathrm{ml})$. After 2 washes of the samples with ethanol (80\%) by mixing, centrifuging and decanting the supernatant, the sediment was transferred with ethanol (80\%) onto a polycarbonate filter $(0.2 \mu \mathrm{m}$ mesh size). Subsequently, the filters were washed twice with $5 \%$ trichloroacetic acid. Samples were heated in $2 \mathrm{M}$ $\mathrm{NaOH}$ for $2 \mathrm{~h}$ in a water bath at $100^{\circ} \mathrm{C}$. One $\mathrm{ml}$ of supernatant was transferred to scintillation vials and $10 \mathrm{ml}$ of Hionic Fluor scintillation fluid was added. For each sample, 3 replicates and 2 ethanol-treated blanks were analysed. Activity in the samples was determined by a $\beta$-counter (TRI-CARB 2900 TR Liquid Scintillation Analyzer).

\section{Statistical analyses}

Differences in chemical and biological parameters among stations were assessed with 1-way ANOVA using STATISTICA. When significant differences were observed ( $p<0.05)$, Tukey's pairwise comparison test was also performed. Only statistically significant data are presented. To highlight interactions between structural and functional variables, the nonparametric Spearman's rank correlation analysis (R) was applied.

Univariate diversity analysis (PRIMER software v.5) was applied to benthic diatom abundances of the surface layer considering richness ( $d$; Margalef 1986), equitability $\left(J^{\prime}\right.$, Pielou 1966), diversity $\left(H^{\prime}\right.$; Shannon $\&$ Weaver 1949) and dominance ( $\lambda$; Simpson 1949).

Principal component analysis (PCA) based on $r$ algorithm (correlation coefficient) was carried out using MATEDIT software (Burba et al. 2008). Simultaneous ordination of biotic and abiotic variables was obtained using first and second autovectors and first and second principal components. PCA was performed considering the following variables, mea- 
sured in the 3 layers of each station: sand, TOC, LOM, chl a, MPB, all tested enzymes and PCP. A $5 \%$ significance level was used for the correlation coefficients.

\section{RESULTS}

\section{Physical-chemical data}

Temperature ranged from $6.8^{\circ} \mathrm{C}$ at $\mathrm{Stn} \mathrm{A} 4$ to $9.8^{\circ} \mathrm{C}$ at Stn A2. A salinity gradient was observed from Stns A1 to A4, indicating that the salt wedge tends to intrude for rather long distances upstream. The lowest PAR at the bottom was measured at Stn A3 due to cloudy weather conditions, although light penetration (\%PAR) was inferior at Stn A2 (Table 2).

Table 2. Physical data measured at the 4 stations. PAR: photosynthetically active radiation. \%PAR: percentage of irradiance measured at the bottom with respect to surface irradiance

\begin{tabular}{|rrrrrrr|}
\hline \multicolumn{3}{|c}{$\begin{array}{c}\text { Stn } \\
\end{array}$} & $\begin{array}{c}\text { Depth } \\
(\mathrm{m})\end{array}$ & $\begin{array}{c}\text { Temp. Salinity } \\
\left({ }^{\circ} \mathrm{C}\right)\end{array}$ & & \multicolumn{3}{c|}{ PAR $\left(\mu \mathrm{mol}\right.$ photons $\left.\mathrm{m}^{-2} \mathrm{~s}^{-1}\right)$} \\
\hline $\mathrm{A} 1$ & 2.6 & 8.6 & 0.2 & 35 & 165 & 21.2 \\
$\mathrm{~A} 2$ & 2.9 & 9.8 & 8.5 & 27 & 287 & 9.4 \\
$\mathrm{~A} 3$ & 3.4 & 7.4 & 21.1 & 12 & 113 & 10.6 \\
$\mathrm{~A} 4$ & 3.6 & 6.8 & 27.3 & 39 & 339 & 11.5 \\
\hline
\end{tabular}

According to Shepard's (1954) classification, the sediment varied from sandy silt at Stns A1 and A2 to clayey silt at Stns A3 and A4 (Table 3). The percentage of sand at Stn A2 was significantly higher when compared to the other 3 stations ( $p<0.001)$. Mean TOC content reached $59.08 \mathrm{mg} \mathrm{g}^{-1}$ at Stn A2 and was twice the mean value recorded at Stn A4 (27.22 mg $\mathrm{g}^{-1}$ ). At the lagoonal Stn A4, TOC values were significantly lower than those measured upstream (p < 0.001). Similarly, the mean LOM value at Stn A2 was ca. $40 \%$ higher than that at Stn A4. LOM accumulation was noticed in the deepest layer at Stns A2 and A3. Except for the surface and subsurface layers at Stn A4, the protein content (50.3 to $72.8 \%$ ) of the sediment was always superior to the lipid one (16.1 to $42.7 \%$ ), whereas total carbohydrates did not exceed $11 \%$ of LOM (Table 3 ). The highest chl a values were measured in the uppermost sediment layers at Stns A2 and A3 (14.85 and $14.58 \mu^{-1} \mathrm{~g}^{-1}$, respectively); chl a content was significantly lower at Stn A4 compared to the values measured upstream $(p<0.01)$.

\section{Benthic communities}

The abundance of benthic prokaryotes ranged between $1.26 \times 10^{9}$ and $4.32 \times 10^{9}$ cells $_{\mathrm{dry}^{-1}}{ }^{-1}$. In the surface layer, a slightly higher abundance was measured at Stn A4 than at the other sites, whereas major densities were observed in the 2-4 $\mathrm{cm}$ layer of Stns A1 and A2. However, no consistent differences

Table 3. Sand content and structural chemical data measured in the 3 sediment layers of the 4 stations. Values are average of 3 replicates $\pm \mathrm{SD}$. TOC: total organic carbon; $\mathrm{CHO}_{\mathrm{EDTA}}$ : EDTA-extractable carbohydrates; $\mathrm{CHO}_{\mathrm{H} 2 \mathrm{O}}$ : colloidal carbohydrates extracted in water; LOM: labile organic matter

\begin{tabular}{|c|c|c|c|c|c|c|c|c|}
\hline $\begin{array}{l}\text { Layer } \\
(\mathrm{cm})\end{array}$ & $\begin{array}{c}\text { Sand } \\
(\%)\end{array}$ & $\begin{array}{c}\text { TOC } \\
\left(\mathrm{mg} \mathrm{C} \mathrm{g}^{-1}\right)\end{array}$ & $\begin{array}{l}\text { Proteins } \\
\left(\mu g \mathrm{Cg}^{-1}\right)\end{array}$ & $\begin{array}{c}\text { Lipids } \\
\left(\mu \mathrm{g} \mathrm{C} \mathrm{g}{ }^{-1}\right)\end{array}$ & $\begin{array}{l}\mathrm{CHO}_{\text {EDTA }} \\
\left(\mu \mathrm{Cg}^{-1}\right)\end{array}$ & $\begin{array}{c}\mathrm{CHO}_{\mathrm{H} 2 \mathrm{O}} \\
\left(\mu \mathrm{Cg} \mathrm{g}^{-1}\right)\end{array}$ & $\begin{array}{c}\mathrm{LOM} \\
\left(\mu \mathrm{C} \mathrm{g} \mathrm{g}^{-1}\right)\end{array}$ & $\begin{array}{c}\text { Chl a } \\
\left(\mu g^{-1}\right)\end{array}$ \\
\hline \multicolumn{9}{|l|}{ Stn A1 } \\
\hline $0-2$ & 19.0 & $56.38 \pm 0.14$ & $5032 \pm 149$ & $1766 \pm 134$ & $256 \pm 26$ & $148 \pm 3.8$ & 7201 & $12.12 \pm 1.82$ \\
\hline $2-4$ & 13.4 & $51.92 \pm 0.27$ & $5639 \pm 174$ & $1644 \pm 75$ & $506 \pm 40$ & $78 \pm 1.8$ & 7867 & $9.53 \pm 1.43$ \\
\hline $4-6$ & 18.4 & $46.16 \pm 0.08$ & $4976 \pm 181$ & $2165 \pm 157$ & $349 \pm 7$ & $112 \pm 3.7$ & 7601 & $7.77 \pm 0.93$ \\
\hline \multicolumn{9}{|l|}{ Stn A2 } \\
\hline $0-2$ & 34.2 & $64.94 \pm 0.20$ & $5928 \pm 108$ & $2436 \pm 214$ & $497 \pm 67$ & $110 \pm 6.1$ & 8971 & $14.85 \pm 2.23$ \\
\hline $2-4$ & 33.7 & $57.07 \pm 0.12$ & $3723 \pm 134$ & $3161 \pm 24$ & $419 \pm 49$ & $101 \pm 1.1$ & 7404 & $9.27 \pm 1.39$ \\
\hline $4-6$ & 28.7 & $55.23 \pm 1.21$ & $6850 \pm 36$ & $4083 \pm 97$ & $436 \pm 11$ & $84 \pm 8.3$ & 11454 & $8.10 \pm 1.13$ \\
\hline \multicolumn{9}{|l|}{ Stn A3 } \\
\hline $0-2$ & 9.5 & $48.83 \pm 0.28$ & $3262 \pm 136$ & $2673 \pm 135$ & $233 \pm 8$ & $103 \pm 10.3$ & 6271 & $14.58 \pm 2.19$ \\
\hline $2-4$ & 20.6 & $44.55 \pm 1.98$ & $3732 \pm 1$ & $2539 \pm 88$ & $295 \pm 14$ & $111 \pm 7.8$ & 6676 & $9.94 \pm 1.49$ \\
\hline $4-6$ & 13.4 & $45.13 \pm 0.21$ & $6897 \pm 2$ & $3296 \pm 156$ & $428 \pm 10$ & $113 \pm 7.0$ & 10734 & $11.51 \pm 2.07$ \\
\hline \multicolumn{9}{|l|}{ Stn A4 } \\
\hline $0-2$ & 4.9 & $29.57 \pm 0.60$ & $1827 \pm 20$ & $2768 \pm 204$ & $190 \pm 14$ & $73 \pm 6.2$ & 4858 & $4.24 \pm 0.64$ \\
\hline $2-4$ & 8.4 & $27.38 \pm 0.34$ & $1623 \pm 84$ & $4338 \pm 88$ & $401 \pm 54$ & $90 \pm 5.9$ & 6452 & $2.75 \pm 0.41$ \\
\hline $4-6$ & 4.9 & $24.72 \pm 0.57$ & $4129 \pm 118$ & $911 \pm 38$ & $512 \pm 24$ & $117 \pm 2.0$ & 5669 & $1.39 \pm 0.21$ \\
\hline
\end{tabular}


Table 4. Biological structural parameters measured in the 3 sediment layers at the 4 stations. For microphytobenthos (MPB), values are average of 3 replicates $\pm \mathrm{SD}$ for the $0-2 \mathrm{~cm}$ layer; the other depth classes had only 1 replicate. $\mathrm{C}_{16}$ : n-hexadecane; MPN: most probable number

\begin{tabular}{|c|c|c|c|c|c|c|c|}
\hline \multirow{2}{*}{$\begin{array}{l}\text { Layer } \\
(\mathrm{cm})\end{array}$} & \multirow{2}{*}{$\begin{array}{c}\text { Prokaryotes } \\
\left(\times 10^{9} \text { cells }\right. \\
\left.g_{\mathrm{dry}}^{-1}\right)\end{array}$} & \multicolumn{3}{|c|}{ - Bacteria (MPN $\mathrm{g}_{\mathrm{dry}}{ }^{-1}$ ) } & \multirow{2}{*}{$\begin{array}{c}\text { MPB } \\
\left(\text { cells } \mathrm{cm}^{-3}\right)\end{array}$} & \multirow{2}{*}{$\begin{array}{l}\text { Meiofauna } \\
\text { (ind. } 10 \mathrm{~cm}^{-2} \text { ) }\end{array}$} & \multirow{2}{*}{$\begin{array}{l}\text { Macrofauna } \\
\text { (ind. } \mathrm{m}^{-2} \text { ) }\end{array}$} \\
\hline & & $\begin{array}{l}\text { Cellulose- } \\
\text { degrading }\end{array}$ & $\begin{array}{l}\text { Petroleum- } \\
\text { degrading }\end{array}$ & $\begin{array}{c}\mathrm{C}_{16^{-}} \\
\text {degrading }\end{array}$ & & & \\
\hline \multicolumn{8}{|l|}{ Stn A1 } \\
\hline $0-2$ & $2.64 \pm 0.10$ & 488 & 92 & 18376 & $514500 \pm 18243$ & $1005.4 \pm 152.0$ & $638.9 \pm 250.2$ \\
\hline $2-4$ & $4.17 \pm 0.57$ & 131 & 112 & 2671 & 216600 & & \\
\hline $4-6$ & $2.04 \pm 0.19$ & 588 & 6 & 1526 & 77400 & & \\
\hline \multicolumn{8}{|l|}{ Stn A2 } \\
\hline $0-2$ & $2.54 \pm 0.36$ & 19 & 39 & 28200 & $247800 \pm 25456$ & $176.0 \pm 64.8$ & $44.4 \pm 9.6$ \\
\hline $2-4$ & $4.32 \pm 0.58$ & 37 & 6 & 21406 & 96000 & & \\
\hline $4-6$ & $1.26 \pm 0.16$ & 10 & 6 & 7439 & 57000 & & \\
\hline \multicolumn{8}{|l|}{ Stn A3 } \\
\hline $0-2$ & $2.39 \pm 0.06$ & 12 & 106 & 3548 & $177300 \pm 8910$ & $1639.5 \pm 162.1$ & $61.1 \pm 9.6$ \\
\hline $2-4$ & $3.28 \pm 0.33$ & 4 & 48 & 759 & 71400 & & \\
\hline $4-6$ & $4.08 \pm 0.17$ & 1 & 12 & 269 & 70200 & & \\
\hline \multicolumn{8}{|l|}{ Stn A4 } \\
\hline $0-2$ & $3.60 \pm 0.32$ & 1 & 33 & 573 & $59400 \pm 1697$ & $3986.2 \pm 1124.1$ & $533.3 \pm 60.1$ \\
\hline $2-4$ & $2.47 \pm 0.27$ & 0 & 41 & 291 & 16800 & & \\
\hline $4-6$ & $2.16 \pm 0.00$ & 0 & 5 & 102 & 3600 & & \\
\hline
\end{tabular}

or dynamics were detected either among stations or among layers.

Cellulose-degrading bacteria enumerated in samples from Stn A1 (up to $588 \mathrm{MPN} \mathrm{g}^{-1}$ ) were one order of magnitude higher than at Stn A2 and presumably related to the past pulp mill activity in the Banduzzi Channel (Stn A1). The ability to degrade cellulose lessened downstream along the Aussa River (Stns A2 to A4) (Table 4). Petroleum-degrading bacteria were more numerous in the surface and subsurface sediments of Stn A1 (92 and $112 \mathrm{MPN} \mathrm{g}^{-1}$, respectively) and in the top layer of Stn A3, whereas at Stn A4 and especially at Stn A2, lower MPN were observed. In contrast, the ability to degrade n-hexadecane was superior at Stn A2 (28 $\left.200 \mathrm{MPN} \mathrm{g}^{-1}\right)$ than at Stn A1 (18376 $\mathrm{MPN} \mathrm{g}^{-1}$ ), which was contaminated by hydrocarbons. Finally, lower n-hexadecane-degrading bacteria numbers were obtained downstream at Stns A3 and A4.

Microalgal abundance decreased downstream (Table 4). At Stn A1, MPB exceeded 500000 cells $\mathrm{cm}^{-3}$ in the uppermost sediment layer, and cell numbers remained extremely high up to a depth of $6 \mathrm{~cm}$. Although the microalgal density at Stn A2 was approximately half of that observed at Stn A1, it was still very high $\left(247800\right.$ cells $\left.\mathrm{cm}^{-3}\right)$. Only at Stn A4, where the lagoonal features were more pronounced, was the MPB abundance of the same order of magnitude as that estimated in marine muddy sediments (Cibic et al. 2007a). The qualitative composition of the MPB community was quite diverse in the 4 investigated sites. Focusing on the surface layer, diatoms dominated at Stn A1, while their percentage decreased downstream (Table 5). In contrast, the contribution of Chlorophyta and Cyanobacteria increased downstream; Chlorophyta were more abundant at Stn A2 and Cyanobacteria at Stn A3. Undetermined phytoflagellates reached a higher relative abundance (RA) at the lagoonal Stn A4. Among diatoms, the most abundant genus at Stn A1 was Craticula, with an RA of $>30 \%$ (Table 5 ).

Diatoma was also abundant, reaching $15.2 \%$ of the total diatom community. At Stn A2, Craticula was still the most abundant diatom genus, followed by Cocconeis (18.6\%) and Melosira. Increasing salinity (21.1) at Stn A3 enhanced the abundance of brackish and marine diatom taxa, such as several species of the genus Gyrosigma. Concomitantly, the RA of predominantly freshwater taxa (Diatoma and several Fragilaria spp.) decreased. At Stn A4, Melosira varians reached the highest RA, followed by Cocconeis placentula.

Univariate diversity indices revealed that the highest richness was observed at Stn A1 ( $d=2.93)$, whereas the highest diversity was found at Stn A3 $\left(H^{\prime}=2.63\right)$. The discrepancy between the 2 indices was due to the dominance of Craticula, which reached an RA of $30 \%$ at Stn A1. The diatom community was rather evenly distributed at Stn A3 ( $J^{\prime}=$ 0.80 at Stn A3 and 0.66 at Stn A1). At this site, the 
most abundant genus, Gyrosigma, did not exceed $15.6 \%$.

Meiobenthic abundances ranged from $176.5 \pm 64.8$ to $3986.2 \pm 1124.1$ ind. $10 \mathrm{~cm}^{-2}$ at Stns A2 and A4, respectively (Table 4). A total of 11 taxa were detected: 7 belonged to permanent meiofauna (Nematoda; Copepoda: Harpacticoida and their nauplius stages; Kinorhyncha; Ostracoda; Rotifera; Tardigrada; Turbellaria). The remaining 4 taxa belonged to temporary meiofauna (juvenile macrofauna: Polychaeta, Oligochaeta, Amphipoda, Nemertina). Nematoda constituted $>90 \%$ of the total meiofaunal community, except for Stn A2, where the RA was $87.1 \%$ (Table 5). Copepoda: Harpacticoida together with their nauplius stages were the second most

Table 5. Relative abundance (\%) of the major groups constituting the 3 benthic communities and the major benthic diatom genera at the 4 stations. Microphytobenthos were analysed in the surface layer $(0-2 \mathrm{~cm})$ and meiofauna in the top $10 \mathrm{~cm}$

\begin{tabular}{|c|c|c|c|c|}
\hline Taxon & A1 & A2 & A3 & A4 \\
\hline \multicolumn{5}{|l|}{ Microphytobenthos } \\
\hline Chlorophyta & 2.2 & 11.0 & 3.7 & 6.6 \\
\hline Cyanobacteria & 1.7 & 9.6 & 17.8 & 3.5 \\
\hline Undet. Phytoflagellates & 0.0 & 1.0 & 1.7 & 15.2 \\
\hline Spores and cysts & 0.3 & 0.5 & 0.5 & 5.6 \\
\hline Bacillariophyta: & 95.7 & 78.0 & 76.3 & 69.2 \\
\hline Amphora & 2.7 & 0.9 & 0.7 & 2.9 \\
\hline Cocconeis & 3.8 & 18.6 & 5.3 & 16.9 \\
\hline Craticula & 31.2 & 21.7 & 11.3 & 1.5 \\
\hline Diatoma & 15.2 & 9.5 & 1.6 & 6.6 \\
\hline Fragilaria & 11.2 & 5.0 & 2.7 & 5.9 \\
\hline Gyrosigma & 1.3 & 0.6 & 20.4 & 4.4 \\
\hline Melosira & 10.1 & 9.8 & 14.0 & 18.4 \\
\hline Navicula & 2.5 & 0.2 & 2.2 & 0.0 \\
\hline Nitzschia & 1.5 & 4.8 & 4.0 & 2.2 \\
\hline Surirella & 0.2 & 3.3 & 3.3 & 0.7 \\
\hline Other diatom genera & 20.4 & 25.6 & 34.6 & 40.4 \\
\hline \multicolumn{5}{|l|}{ Meiofauna } \\
\hline Copepoda & 0.2 & 0.9 & 3.0 & 1.4 \\
\hline Nauplii & 0.0 & 0.9 & 4.7 & 2.7 \\
\hline Nematoda & 93.4 & 87.1 & 91.2 & 93.5 \\
\hline Polychaeta & 0.0 & 0.9 & 0.0 & 0.9 \\
\hline Rotifera & 1.9 & 3.1 & 0.0 & 0.0 \\
\hline Tardigrada & 2.3 & 0.3 & 0.0 & 0.0 \\
\hline Others & 0.2 & 2.5 & 0.2 & 1.1 \\
\hline Incertae sedis & 2.0 & 4.1 & 0.8 & 0.4 \\
\hline \multicolumn{5}{|l|}{ Macrofauna } \\
\hline Chironomus & 99.1 & 37.5 & 0 & 0 \\
\hline Gammaridae & 0 & 0 & 0 & 1.0 \\
\hline Incertae sedis & 0 & 0 & 0 & 2.1 \\
\hline Muricidae & 0 & 0 & 0 & 2.1 \\
\hline Polychaeta cf. Nereidae & 0 & 50 & 100 & 39.6 \\
\hline Sadleriana fluminensis & 0.9 & 0 & 0 & 0 \\
\hline Sternaspis scutata & 0 & 12.5 & 0 & 55.2 \\
\hline
\end{tabular}

abundant group, with RA ranging from $0.2 \%$ to $7.7 \%$ at Stns A1 and A3, respectively.

Macrobenthic organisms were more abundant at Stns A1 $\left(638.9 \pm 250.2\right.$ ind. $\left.\mathrm{m}^{-2}\right)$ and A4 (533.3 \pm 60.1 ind. $\mathrm{m}^{-2}$ ) than at the other 2 sites (Table 4). At Stn A1, larvae of Chironomus dominated, with an RA of $99.1 \%$ (Table 5). These organisms were also observed at Stn A2, constituting $37.5 \%$ of the total macrozoobenthic community. The Polychaeta cf. Nereidae was seen along the Aussa River (Stns A2 to A4) but not in the Banduzzi Channel (Stn A1). Its RA varied considerably, ranging from $39.6 \%$ at Stn A4 to $100 \%$ at Stn A3. However, this latter value corresponded to only $61.1 \pm 9.6$ ind. $\mathrm{m}^{-2}$, compared to $211.1 \pm 9.6$ ind. $\mathrm{m}^{-2}$ at Stn A4. Another polychaete, Sternaspis scutata (RA: $55.2 \%$ ), characterised the macrozoobenthic community in this lagoonal area.

\section{Functional parameters}

$\mathrm{PP}_{\mathrm{s}}$ decreased from Stn A1 to Stn A4, following MPB abundance dynamics (Fig. 2). Although estimates were carried out at the end of December in low light conditions ( $35 \mu \mathrm{mol}$ photons $\left.\mathrm{m}^{-2} \mathrm{~s}^{-1}\right)$, a very high $\mathrm{PP}_{\mathrm{s}}$ value was obtained at Stn A1 $\left(7.2 \mu \mathrm{g} \mathrm{C} \mathrm{cm}{ }^{-3} \mathrm{~h}^{-1}\right.$,
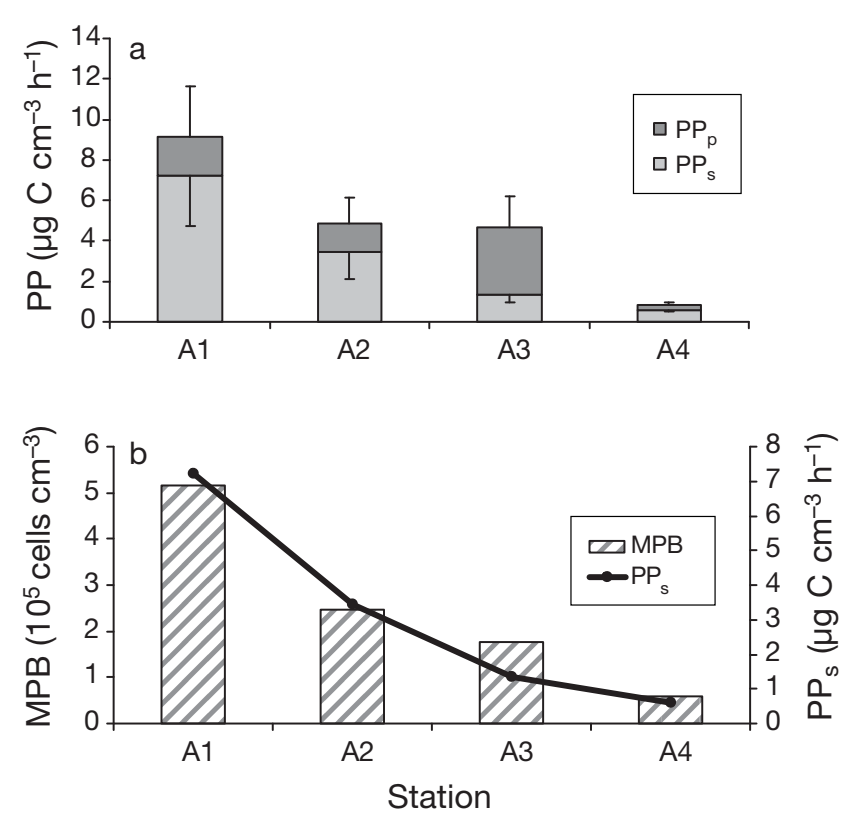

Fig. 2. (a) Microphytobenthic primary production (PP) as estimated at in situ conditions $\left(\mathrm{PP}_{\mathrm{s}}\right)$ and the potential $\mathrm{PP}$ $\left(\mathrm{PP}_{\mathrm{p}}\right)$ corresponding to the highest value obtained when exposing the community to a light gradient (from 20 to $200 \mu \mathrm{mol}$ photons $\mathrm{m}^{-2} \mathrm{~s}^{-1}$ ). (b) $\mathrm{PP}_{\mathrm{s}}$ and microphytobenthic abundance (MPB) 


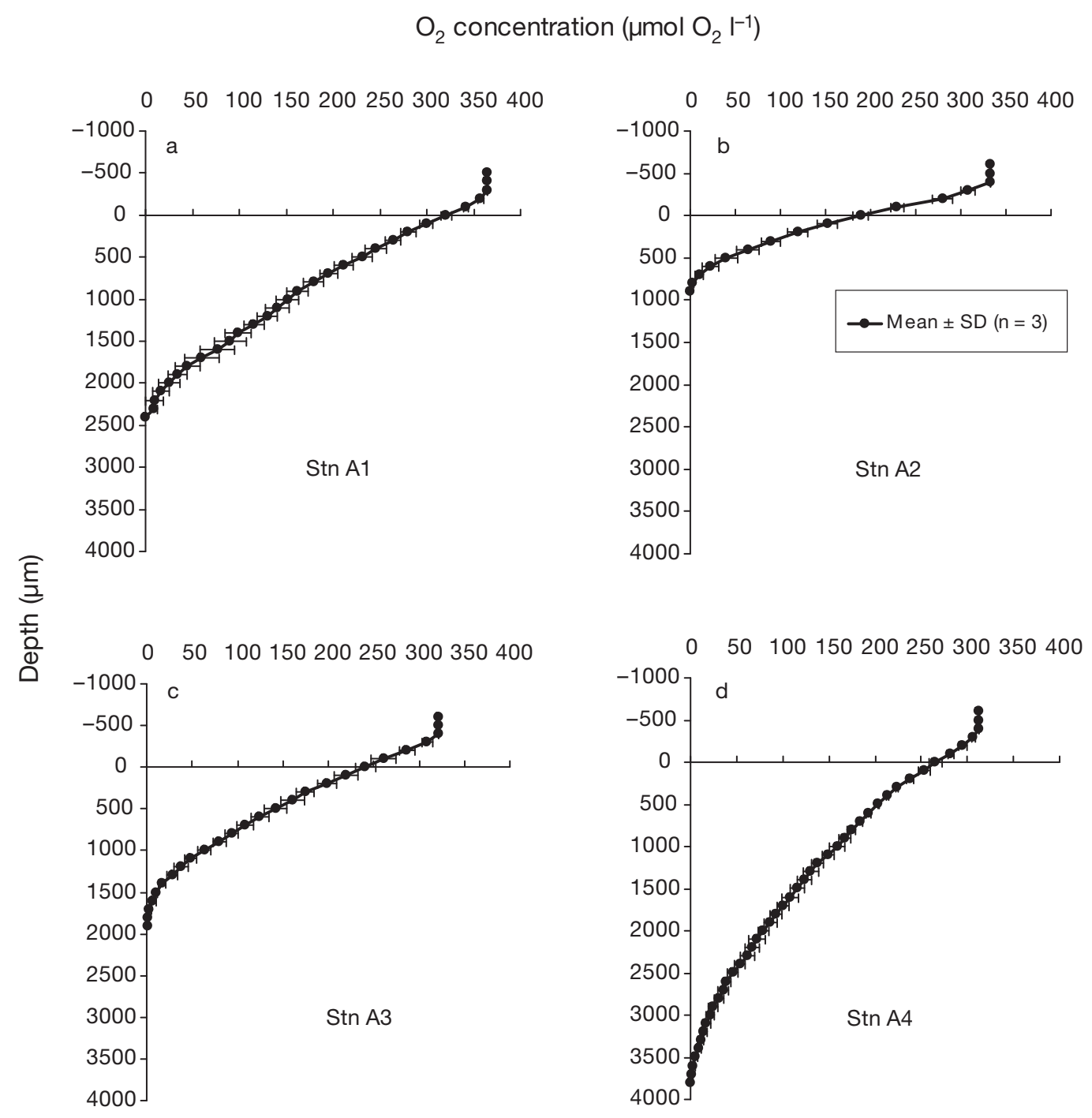

Fig. 3. $\mathrm{O}_{2}$ microprofiles estimated in sediment core samples from (a) the Banduzzi Channel (Stn A1) and (b-d) along the Aussa River (Stns A2 to A4)

corresponding to $20.6 \mathrm{mg} \mathrm{C} \mathrm{m}^{-2} \mathrm{~h}^{-1}$ ). Without taking into account the contribution of macrophytes or aquatic phanerogams, this value was entirely due to the abundant MPB community. Not only was the microalgal community very abundant, but it was also photosynthetically active. In particular, Craticula and Melosira cells appeared viable, with a high pigment content. Overall, MPB seemed to be low-light adapted. In fact, after exposing the microalgae to increasing light intensities, the maximum $\mathrm{PP}_{\mathrm{p}}\left(9.1 \mu \mathrm{g} \mathrm{C} \mathrm{cm}{ }^{-3} \mathrm{~h}^{-1}\right)$ was measured at $50 \mu \mathrm{mol}$ photons $\mathrm{m}^{-2} \mathrm{~s}^{-1}$, whereas at higher light intensities they showed photoinhibition. Although $\mathrm{PP}_{\mathrm{s}}$ at Stn $\mathrm{A} 2$ was higher than that at Stn $\mathrm{A} 3$, comparable $\mathrm{PP}_{\mathrm{p}}$ values were estimated in the 2 sites. This is probably because sampling at Stn A3 was performed in cloudy conditions, which cause low surface PAR (113 $\mu \mathrm{mol}$ photons $\left.\mathrm{m}^{-2} \mathrm{~s}^{-1}\right)$.

Oxygen microprofiles revealed that oxygen penetration depth was quite diverse among the 4 sites (Fig. 3). In particular the thickness of the oxic layer at Stn A2 was exceedingly reduced and the oxygen was completely consumed within the top $0.8 \mathrm{~mm}$. In contrast, oxygen penetration at the lagoonal Stn A4 reached a depth of $3.7 \mathrm{~mm}$. At both Stns A1 and A3, the microprofiles showed intermediate dynamics between Stns A2 and A4. Oxygen consumption rates were calculated from the microprofiles performed in darkness. 
The maximum oxygen consumption was observed at Stn A2 (Fig. 4a). The value at Stn A3 was 5 times lower at Stn A2, whereas Stns A1 and A4 showed comparable and modest rates. Data were converted to $\mathrm{mg} \mathrm{C} \mathrm{m} \mathrm{C}^{-2} \mathrm{~h}^{-1}$ to allow an estimation of the trophic status (autotrophy or heterotrophy) of the investigated sites. Gross primary production (GPP) represents the sum of net primary production (NPP) and community respiration (CR). The ${ }^{14} \mathrm{C}$ technique measures something between GPP and NPP, depending on the incubation time: shorter incubation times are closer to GPP whereas incubation times $\geq 6 \mathrm{~h}$ are closer to NPP (Gazeau et al. 2004). In our case, the incubation time was about $45 \mathrm{~min}$, and therefore a GPP rate was measured. We attempted to estimate NPP by subtracting CR, assessed as oxygen consumption in the dark. In the Banduzzi Channel (Stn A1), only the benthic system was net-autotrophic, whereas along the Aussa River (Stns A2 to A4), the benthic community was net-heterotrophic (Fig. 4b).

The highest enzymatic activities were directed to the degradation of proteins. In all 4 sites, the leucineaminopeptidase activity was more pronounced in the surface layer, with decreasing values towards the deeper layers (Fig. 5a). As in the subsurface sediment of all 4 sites, comparable values were obtained, but a remarkable difference was observed between the
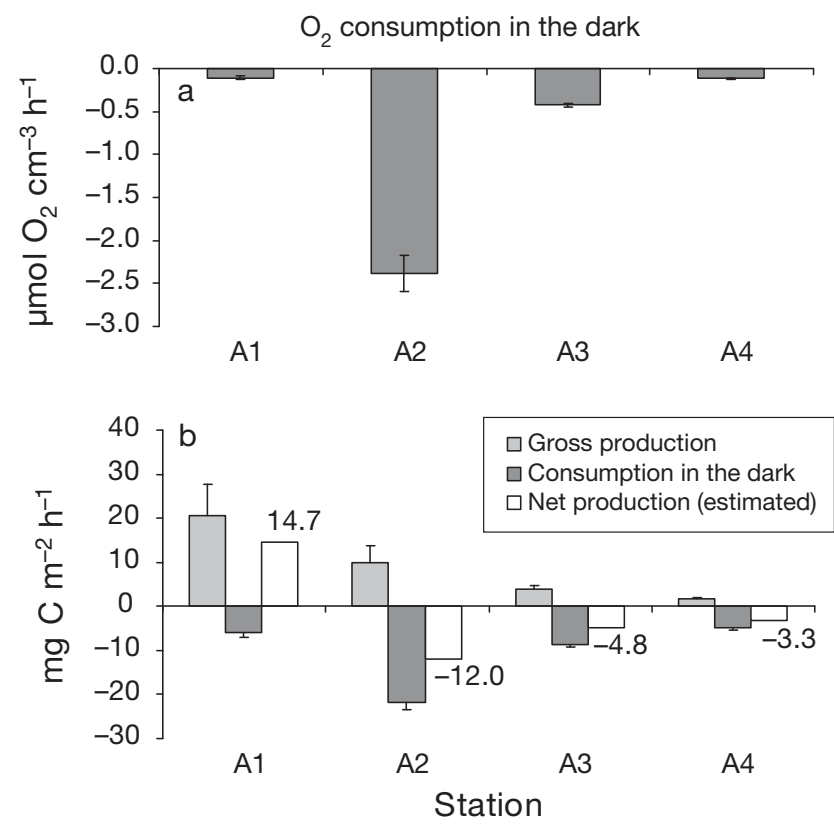

Fig. 4. (a) $\mathrm{O}_{2}$ consumption rates estimated in darkness and at in situ temperature in the 4 studied areas; (b) rates of gross production (from ${ }^{14} \mathrm{C}$ data), consumption (converted from $\mathrm{O}_{2}$ consumption data) and net production (estimated) top layers of the Banduzzi Channel (Stn A1) and the Aussa River (Stns A2 to A4). At Stn A1, a lower hydrolysis was estimated $\left(142.2 \pm 4.8 \mathrm{nmol} \mathrm{cm}{ }^{-3} \mathrm{~h}^{-1}\right)$, whereas the degradation of polypeptides displayed higher values at the other stations, with a decreasing gradient along the Aussa River (from $310.8 \pm$ $30.9 \mathrm{nmol} \mathrm{cm}^{-3} \mathrm{~h}^{-1}$ at Stn A2 to $193.3 \pm 17.7 \mathrm{nmol}$ $\mathrm{cm}^{-3} \mathrm{~h}^{-1}$ at Stn A4). In contrast, alkaline phosphatase was more active at Stn A1, with decreasing values from the surface $\left(67.0 \pm 0.1 \mathrm{nmol} \mathrm{cm}{ }^{-3} \mathrm{~h}^{-1}\right)$ to the deepest layer $\left(41.6 \pm 1.9 \mathrm{nmol} \mathrm{cm}^{-3} \mathrm{~h}^{-1}\right)$ (Fig. 5b). Significantly lower rates were found at Stns A2 and A3 ( $p<0.001$ ) compared to Stn A1, with no remarkable differences either among layers or between sites, while intermediate values were found at Stn A4 (mean of 3 layers: $27.4 \pm 3.6 \mathrm{nmol} \mathrm{cm}^{-3} \mathrm{~h}^{-1}$ ). Degradation of polysaccharides was evaluated via hydrolysis of $\alpha$-glycosidic bonds, typical of starch, and $\beta$-glycosidic bonds, typical of linear molecules such as cellulose. In all 4 sites, the activity of $\alpha$-glucosidase was lower than that of $\beta$-glucosidase (Fig. 5c,d). The highest rates of $\alpha$-glucosidase were estimated in the Banduzzi Channel (Stn A1). Decreasing $\alpha$-glucosidase rates were displayed both downstream and from the surface to the deeper layers. In contrast, $\beta$-glucosidase activity at Stn A1 was significantly lower ( $\mathrm{p}<$ 0.05) compared to those along the Aussa River (Stns A2 to A3), where decreasing values were estimated downstream. The highest rate was reached in the surface layer of Stn A2 $\left(22.6 \pm 0.1 \mathrm{nmol} \mathrm{cm}{ }^{-3} \mathrm{~h}^{-1}\right)$, whereas the minimum was obtained in the $4-6 \mathrm{~cm}$ layer at Stn A4 $\left(3.9 \pm 0.1 \mathrm{nmol} \mathrm{cm} \mathrm{cm}^{-3} \mathrm{~h}^{-1}\right)$. Lipase was the least active among the tested enzymes. Similarly to protease, decreasing hydrolysis rates were observed from the top to the bottom layer (Fig. 5e). Slightly higher values were measured in the surface sediment of Stns A1 and A2 (5.30 and $5.67 \mathrm{nmol} \mathrm{cm}{ }^{-3}$ $\mathrm{h}^{-1}$, respectively) compared to Stns A3 and A4 (3.79 and $3.11 \mathrm{nmol} \mathrm{cm}^{-3} \mathrm{~h}^{-1}$, respectively).

The microbial community was significantly more active in the Banduzzi Channel (Stn A1) than along the Aussa River (Stns A2 to A4) ( $p<0.01$ ) (Fig. 5f). At Stn A1, high and comparable PCP values were estimated in the surface and subsurface layers $(0.77 \pm$ 0.06 and $0.77 \pm 0.07 \mu \mathrm{g} \mathrm{C} \mathrm{cm}{ }^{-3} \mathrm{~h}^{-1}$, respectively), and even in the $4-6 \mathrm{~cm}$ layer a higher rate $(0.63 \pm 0.05 \mu \mathrm{g}$ $\mathrm{C} \mathrm{cm}^{-3} \mathrm{~h}^{-1}$ ) was measured compared to the other 3 stations. Along the Aussa River, the maximum secondary production in the surface sediment was displayed at the lagoonal Stn A4 $0.53 \pm 0.07 \mu \mathrm{g} \mathrm{C} \mathrm{cm}^{-3}$ $\mathrm{h}^{-1}$ ), with decreasing values upstream.

The highest prokaryotic C efficiency was calculated at Stn A1 (6.21\%), while decreasing efficiencies 

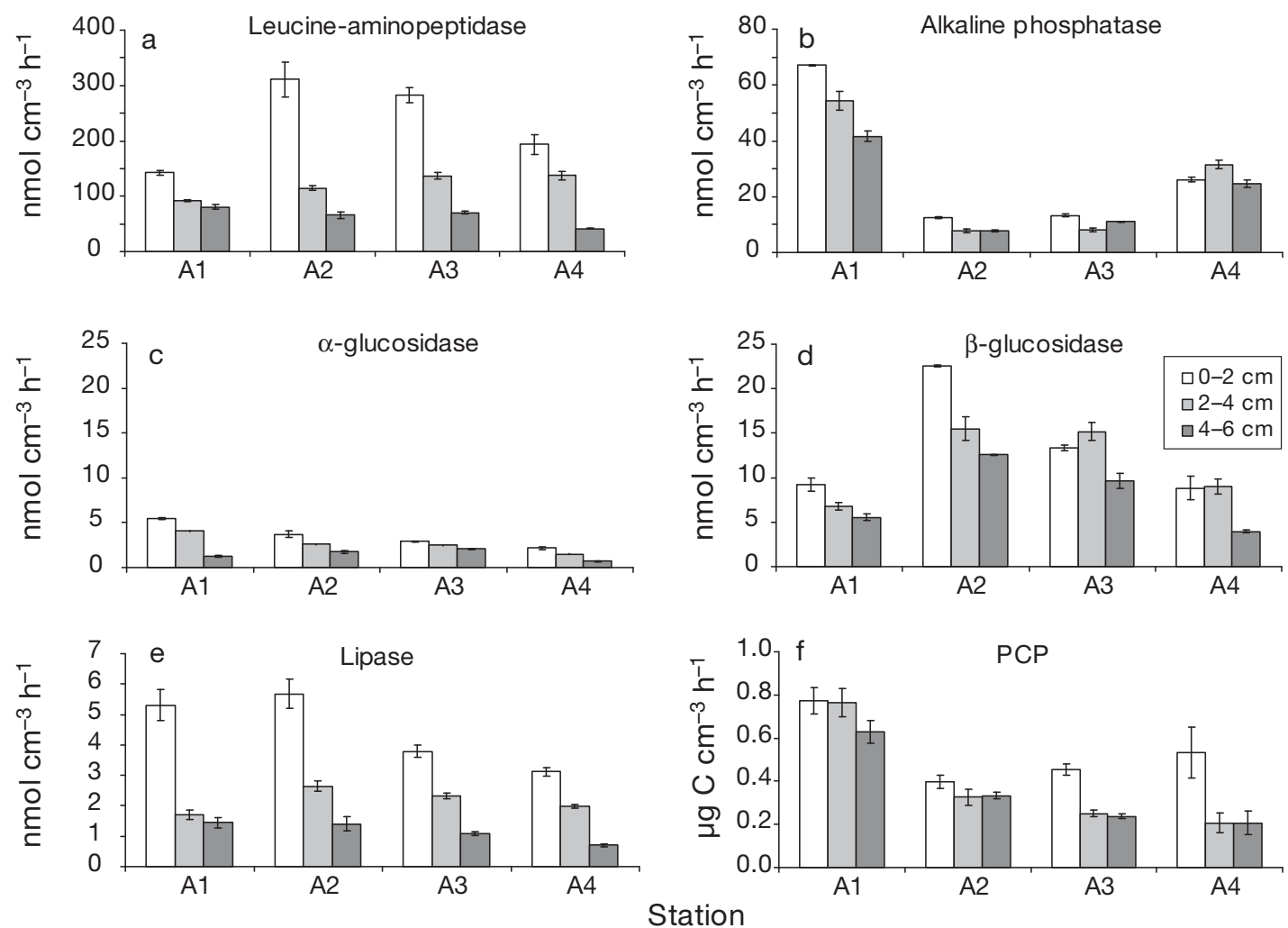

Fig. 5. Extracellular enzymatic activities and prokaryotic carbon production (PCP) in each sediment layer of each station: (a) leucine-aminopeptidase, (b) alkaline phosphatase, (c) $\alpha$-glucosidase, (d) $\beta$-glucosidase, (e) lipase, (f) PCP

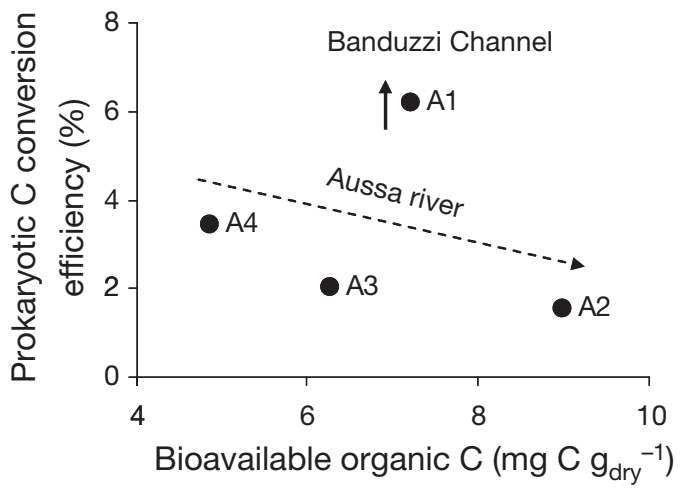

Fig. 6. Relationship between labile organic matter and prokaryotic $\mathrm{C}$ conversion efficiency determined as the ratio of prokaryotic $\mathrm{C}$ production and the amount of $\mathrm{C}$ degraded enzymatically and expressed as a percentage (as proposed by Danovaro \& Pusceddu 2007). Data refer to the surface sediment layer

were observed upstream, from Stn A4 to Stn A2 (Fig. 6). Although no evident differences in the prokaryotic numbers were observed among the 4 studied areas, in the Banduzzi Channel (Stn A1) the microbial community seemed to be the most efficient in transforming the organic C pool into biomass. While degradation rates of lipids, polypeptides and carbohydrates at Stn A2 were higher than those estimated in the other 3 sites, the prokaryotic community was less efficient in transferring organic $\mathrm{C}$ to higher trophic levels.

\section{PCA}

The ordination plot of the considered structural and functional parameters accounted for $74.5 \%$ of the total variance (Fig. 7). Principal component axis 1 (PC1) explained $47.5 \%$ of the total variance and was correlated with TOC (0.88), chl a (0.87) and $\alpha$ glucosidase (0.86). Principal component axis 2 (PC2) explained $27.0 \%$ of the remaining variance and was correlated with phosphatase $(-0.90)$. The PCA separated well the 4 sites that were positioned along a decreasing gradient of organic load, from Stn A2, through Stns A3 and A1, to Stn A4. Stn A4 was characterised by more lagoonal features, minor organic content and lower enzymatic activities. 


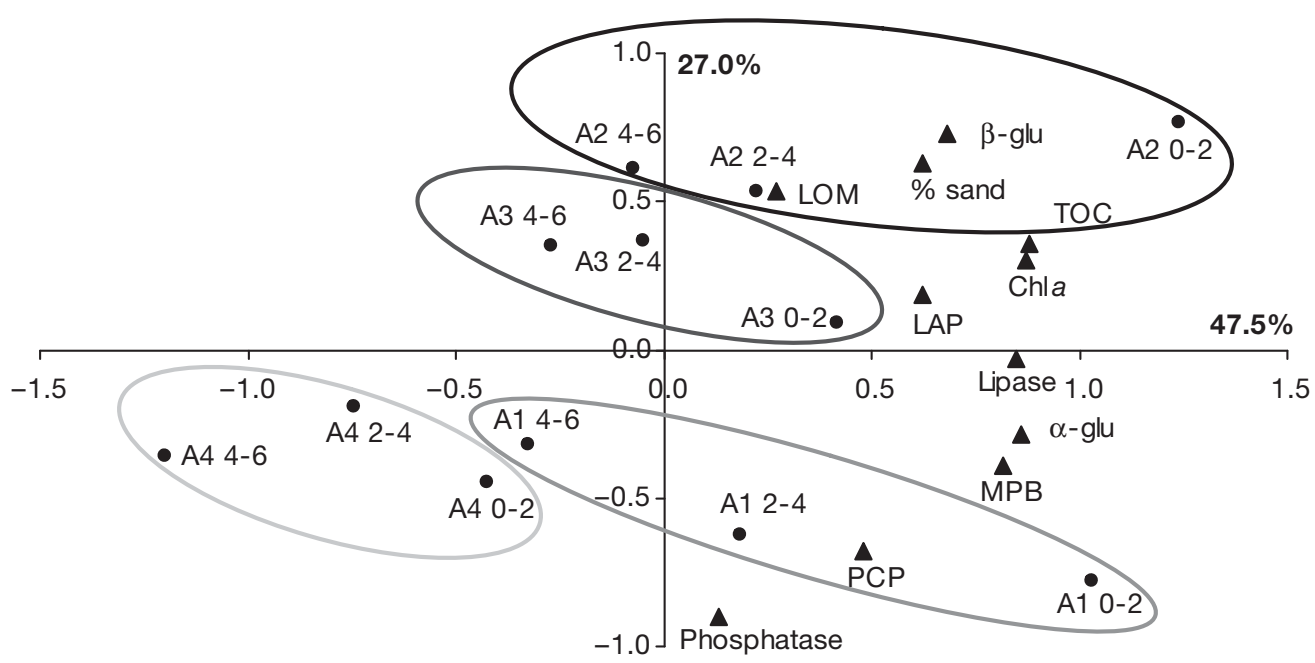

Fig. 7. Principal component analysis, based on $\mathrm{r}$ algorithm, of structural and functional parameters $(\boldsymbol{\Lambda})$ and samples $(\bullet)$ measured in the 3 sediment layers $(0-2,2-4$ and $4-6 \mathrm{~cm}$ ) of the 4 sites (Stns A1 to A4). LOM: labile organic matter; TOC: total organic carbon; MPB: microphytobenthos; PCP: prokaryotic carbon production; LAP: leucine-aminopeptidase; $\alpha$-glu: $\alpha$-glucosidase; $\beta$-glu: $\beta$-glucosidase

\section{DISCUSSION}

\section{Synergistic effect of contaminants}

The Banduzzi Channel is a nutrient-rich site and is severely polluted by several contaminants: heavy metals, hydrocarbons, dioxins and pesticides. Whilst some contaminants (e.g. heavy metals, pesticides) have an inhibitory effect, other compounds (e.g. nutrients, hydrocarbons) can have a stimulatory effect on the riverine food web. The resulting effect on the benthic communities is hardly predictable. For instance, high levels of $\mathrm{N}$ and $\mathrm{P}$ contained in pulp mill effluents discharged in the channel may stimulate primary producers (Culp et al. 2000). Phosphorus may also reduce the impact of elevated metals on biofilms by complexing metals (Fleeger et al. 2003 and references therein). Moreover, lignins in pulp mill effluent and other dissolved organic molecules are known to bind metals and thus affect their availability (Podemski \& Culp 2001 and references therein). Petroleum hydrocarbons represent a significant source of organic matter that may stimulate bacterial productivity or biomass. These in turn support a bottom-up response of bacterivorous and/or depositfeeding species. However, metals and insecticides do not appear to stimulate bacterial production and no evidence of bottom-up effects from these contaminants has been found (Fleeger et al. 2003 and references therein). Differences in chemical behaviour in marine and freshwater habitats may also contribute to different responses. For example, metal toxicity is in general negatively correlated with salinity due to effects on free metal ion concentration, while the toxicity of organo-phosphate insecticides increases with salinity.

\section{Microbial response to contamination}

Microbial communities in human-stressed environments are of paramount importance. Therefore the study of their composition and functioning is highly relevant in the mitigation of problems already present in our environment (Nogales et al. 2011). The total abundance of benthic prokaryotes in the Banduzzi Channel did not show significant differences compared to the other 3 sites. However, the enumeration of functional bacterial groups cultured on specific media indicated the presence of bacteria capable of degrading $n$-hexadecane and petroleum in this site. Typically, 16S rRNA gene sequences related to known hydrocarbon degraders are not (or seldom) detected in assemblages collected in chronically hydrocarbon-polluted areas. Nevertheless, they might become predominant when transferred to polycyclic aromatic hydrocarbon (PAH)-enriched culture media. This might indicate that those hydrocarbon degraders are active but constitute a minor component of these communities, and therefore are not evidenced by most fingerprinting techniques (Nogales et al. 2011). Our results are in accordance with those 
of Carman et al. (1996), who reported that total bacterial abundance was not significantly affected by diesel-contaminated sediment. In contrast to bacterial abundance, those authors found that the bacterial degradation of ${ }^{14} \mathrm{C}$-phenanthrene increased considerably in diesel-contaminated sediment. They suggested that the total number of PAH-degrading bacteria is insignificant in comparison with the total bacterial community and/or that resident assemblages have the capacity to switch to PAH utilisation. However, those authors also reported that ${ }^{3} \mathrm{H}$-leucine incorporation was remarkably consistent among their treatments. This is in contrast with our data, since we found the highest secondary production at the contaminated Stn A1. In this site, together with a severe hydrocarbon contamination, bleached kraft mill effluents were spilled into the Banduzzi Channel from the 1940s until 1992; such effluents increase microbial production as a result of phosphorus enrichment (Culp et al. 2000). In fact, at Stn A1 a very high concentration of total phosphorus has been estimated (Table 1). Furthermore, the transformation of hydrocarbons into biomass by PAH degraders might increase the availability of utilisable organic $\mathrm{C}$, ultimately stimulating PCP rates.

Among the functional microbial groups, we also tested cellulose-degrading organisms, which were highly abundant in the impacted site. Since cellulose is one of the waste products of pulp mill activity, the Banduzzi Channel was likely enriched in this organic compound. This allowed the development of microbial assemblages able to exploit the not-readilyavailable resource. The amount of cellulose degraders retrieved in the deeper sediment layers suggests that high cellulose loads are present not only in the upper $2 \mathrm{~cm}$, but up to $6 \mathrm{~cm}$ depth. This has to imply its burial during the years, accompanied by a long-term evolution of this functional group at this site. The amount of cellulose-degrading microbes found along the Aussa River was much lower (10- to 100-fold), possibly reflecting the decreasing quantity of land plant-derived material while proceeding into the lagoon.

The extremely high abundance of benthic diatoms suggests that they are not influenced by heavy metals and hydrocarbon contamination in the Banduzzi Channel. Benthic diatom mats are rich in extracellular polymeric substances (EPS), which may function as a protective barrier against toxic compounds, as well as enhance the uptake of favourable ones. This feature could decrease the microbial mats' vulnerability to toxic compounds (Sundbäck et al. 2007 and references therein). Moreover, high organic C con- tents were measured at Stns A1 and A2 (Table 3). There is still little information about the combined effect of pollutants' organic load on diatoms. Overall, higher levels of contaminant are required to elicit toxic effects in sediments that are high in organic material (Carman et al. 1995 and references therein). The few existing studies on combined nutrient-stressor effects have generally found that nutrient-rich systems are less sensitive to stressors (Sundbäck et al. 2007 and references therein). We surmise that the toxic effect that might have been induced by heavy metals and organic pollutants on benthic diatoms in our study site was hidden by the stimulating effect of the organic load.

\section{Benthic community structure at higher trophic levels}

Total meiofaunal density was inversely related to microalgal abundance. The meiofauna was mainly composed of nematodes and harpacticoid copepods, which are the major consumers of benthic microalgae (Cibic et al. 2009). Under low grazing pressure, microalgae can develop relatively undisturbed (the impact of viral infection on benthic microalgae is scarcely known; Danovaro et al. 2008) and reach very high densities. Our results agree with Fleeger et al.'s (2003) review, which reported that primary producers, including microalgae, increased in numbers after contaminant-induced impacts on grazers in $60 \%$ of the reviewed studies. Strong top-down effects were found in studies of both freshwater and marine benthic systems: when grazers were selectively impacted by direct effects, metals, hydrocarbons and insecticides, they all elicited trophic cascades. However, there is no direct proof of these mechanisms other than the negative dynamics between the increase in microalgal biomass and decrease in meiofaunal abundance.

Surprisingly, meiobenthic abundance in the impacted Banduzzi Channel was higher than the one recorded at Stn A2. Not all studies reviewed by Carman et al. (1995) showed a negative impact of hydrocarbons on meiofaunal communities. Meiofauna in sediments of natural hydrocarbon seeps are either unaffected by oil or show rises in densities related to increased microbial and/or microalgal food resources. Diatoms exposed to bleached kraft mill effluents enhance their lipid content and may become a higher-quality food source for grazers. Increased dietary lipids have been proved to reduce toxicity (Podemski \& Culp 2001). The lowest RA of 
harpacticoids observed at Stn A1 confirmed that these organisms are more sensitive than nematodes to a variety of substances, including PAH (Carman et al. 1995).

The meiobenthic community seemed to be affected by the low oxygen availability detected at Stn A2 because the meiofaunal density was drastically lower than those recorded in the other areas. Most meiobenthic organisms are generally found in the top $2 \mathrm{~cm}$ of the sediment, which typically display oxic conditions. Copepods are one of the most sensitive taxa to oxygen limitation and therefore they are confined to the oxic sediment layer (Danovaro et al. 2004 and references therein). In fact, we found the absolute maximum of copepods at Stn A4 (55.33 ind. $10 \mathrm{~cm}^{-2}$ ), in correspondence with the highest oxygen penetration in the sediment. At Stn A3, the intermediate oxygen availability could have led to a slightly reduced abundance (48.69 ind. $10 \mathrm{~cm}^{-2}$ ), whereas at Stn A2, the thinnest oxic layer resulted in the lowest copepod density (1.66 ind. $10 \mathrm{~cm}^{-2}$ ). Although nematodes are considered to be tolerant to hypoxia (Danovaro et al. 2004 and references therein), their abundance at Stn A2 did not exceed 153.3 ind. $10 \mathrm{~cm}^{-2}$, suggesting that factors other than or in addition to oxygen influenced the faunal abundance in this site.

The macrozoobenthic community at Stn A1 was dominated by chironomid larvae, while the assemblage at Stn A4 was more diverse. Our data agree with the findings of Sconfietti \& Marchini (2001), who reported that the macrobenthic communities in the innermost sites of the Stella and Aussa estuaries were biologically poorer than the lagoon one, characterised by the highest Shannon diversity index. The occurrence of Chironomus larvae at Stn A1 is also in accordance with the results of Sconfietti \& Marchini (2001), who observed these organisms at the innermost station of the Stella River in the Marano Lagoon. Family Chironomidae is frequently the most abundant group of insects in freshwater environments, and its wide range of tolerance to environmental conditions, e.g. salinity and substrate, is well recognised (Pinder 1986). Many species of chironomid larvae are tolerant of poorly oxygenated conditions because they have haemoglobin. Heavy-metals pollution stress has been reported to virtually eliminate all invertebrates, except chironomids and oligochaetes (Pinder 1986 and references therein). Their dominance in the Banduzzi Channel could also be related to food availability. Diatoms are frequently a conspicuous component of the chironomid larvae diet in freshwater aquatic systems (Pinder 1986) as well as in coastal benthic ecosystems (Goldfinch \& Carman 2000). Lipids are phagostimulants to some aquatic insects, thus, algae with a higher lipid content may become more palatable or attractive to grazers, leading to major growth and increased size of aquatic insects (Podemski \& Culp 2001).

\section{Benthic ecosystem functioning in contaminated sediments}

PP decreased from Stn A1 to Stn A4. Especially at Stn A1 we estimated a very high $\mathrm{PP}_{\mathrm{s}}$ rate, $>20 \mathrm{mg} \mathrm{C}$ $\mathrm{m}^{-2} \mathrm{~h}^{-1}$, indicating that a highly photosynthetically active microalgal community developed on and within these contaminated sediments. This high $\mathrm{PP}_{\mathrm{s}}$ rate was probably due to a combination of different factors. Firstly, the microalgal community was welladapted to low light conditions, typical of the winter months. Secondly, the community was not subjected to excessive grazing pressure. Thirdly, through the photosynthetic process, pennate diatoms extruded high amounts of EPS, creating a protective barrier against toxic compounds, which enabled them to be more resistant to contaminants. Finally, the community was not limited by nutrients, which were regenerated by an extremely active prokaryotic community. Our data are in accordance with those of Carman et al. (1995), who reported elevated incorporation of ${ }^{14} \mathrm{C}$ and high chl a values in their high-PAH treatments, suggesting that microalgal growth was stimulated in the high PAH treatments. Moreover, in our study the highest $\mathrm{PP}_{\mathrm{s}}$ rate was recorded in conjunction with the highest prokaryotic $\mathrm{C}$ efficiency, thus suggesting that prokaryotic activity could enhance primary producers by providing nutrients. Bacteria in contaminated sediments metabolise $\mathrm{N}$ from an otherwise refractory pool of organic material. For instance, PAH degraders, which become enriched in diesel fuel-contaminated sediments because of their ability to co-metabolise complex ring structures, may also metabolise complex ring structures that contain $\mathrm{N}$, such as detrital chlorophyll and phenolic and humic materials. Previous studies have shown that inputs of 'new' or 'labile' carbon to a system may enhance the decay of refractory carbon in sediments via the process of microbial stimulation or co-metabolism (Carman et al. 2000 and references therein).

At Stn A2, the oxygen consumption was much higher than in the 3 other sites. This is peculiar if we consider that at Stn A2 the sand percentage (34\%) was higher than that measured for instance at Stn A4 
(5\%). Sandy sediments usually favour a deeper oxygen penetration compared to muddy sediments. Moreover, considering the particularly low meio- and macrobenthic abundances, the enhanced oxygen consumption rate may not be ascribable to respiration by larger benthic organisms either. The oxygen demand was likely due to degradation of the high organic load in this site (LOM: $>11 \mathrm{mg} \mathrm{C} \mathrm{g}^{-1}$ ). Our results agree with those of Christensen et al. (2003), who found that oxygen consumption, measured by microprofiles, increased in the organic-rich sediments, thus resulting in a net-heterotrophic benthic community.

Prokaryotic activities, estimated both as enzymatic degradation and carbon production, are important factors affecting the transfer of detritus towards higher trophic levels. Alkaline phosphatase, essential for the mineralisation of $\mathrm{PO}_{4}{ }^{3-}$ from organic molecules, is used by both prokaryotes and microalgae to meet their metabolic phosphorus requirements. The highest rate of alkaline phosphatase activity was measured at Stn A1, in correspondence with the maximum abundance of MPB. Due to this enzymatic activity, the increased availability of $\mathrm{PO}_{4}{ }^{3-}$ could promote $\mathrm{PP}$, thus contributing to support the overall benthic system functioning of the contaminated site where the highest PP rates were measured. High PP, together with fast P regeneration, could have fuelled secondary production rates (PCP), which were the highest in this site, too. Comparing our PCP data (converted in $\mathrm{g}$ dry sediment) with those of Manini et al. (2003) for the eutrophicdystrophic Lesina Lagoon, the values obtained in the Banduzzi Channel were 3 times higher $(3.1 \mu \mathrm{g} \mathrm{C}$ $\mathrm{g}^{-1} \mathrm{~h}^{-1}$ ) than those reported by those authors in winter (0.7 to $\left.1.1 \mu \mathrm{g} \mathrm{C} \mathrm{g}^{-1} \mathrm{~h}^{-1}\right)$, whereas values obtained along the Aussa River were comparable. High $\mathrm{PP}_{\mathrm{s}}$ and PCP rates, together with relatively low respiration rates (Fig. 4b), suggest an increased transformation of $\mathrm{C}$ (organic and inorganic) into biomass, possibly leading to an enhanced transfer of $\mathrm{C}$ to higher trophic levels. However, since predators' abundances were not particularly pronounced at this site, this scenario reflects into a solid benthic microbial loop (Caumette 1992, Deming \& Barross 1993), with the possible intervention of functional microbial groups, capable of exploiting non-labile material such as hydrocarbons and cellulose of industrial origin.

Degradation of polysaccharides seemed to follow the dynamics of PP and microalgal abundance along the Aussa River with decreasing rates to the lagoonal station. It is noteworthy that leaf detritus was present in our samples, with decreasing content towards the lagoon (data not shown). Therefore glucosidase activity could also be linked to the presence of nonreadily usable type substrate. In contrast, the intense photosynthetic activity in the Banduzzi Channel probably increased the amount of labile carbohydrates, which can be easily metabolised by prokaryotes without requiring further hydrolytic processes.

Unlike other Mediterranean lagoons (Manini et al. 2003), in our samples, proteins were always higher than carbohydrates, possibly being the cause for high polypeptide hydrolysis rates (with respect to other degradation processes). Comparing our leucineaminopeptidase results with those reported by Manini et al. (2003), we obtained values ranging from 432 to $993 \mathrm{nmol} \mathrm{g}^{-1} \mathrm{~h}^{-1}$ in the top sediment layer at Stns A4 and A2, respectively, while rates reported by those authors in winter were much lower, varying from 9.6 to $304.7 \mathrm{nmol} \mathrm{g}^{-1} \mathrm{~h}^{-1}$.

The relation between MPB and lipase $(\mathrm{R}=0.69, \mathrm{p}<$ 0.05 ) was likely ascribable to the high content of fatty acids in diatom cytoplasm. Microalgae react to toxicant stress with a change in cellular macromolecule content, generally increasing their lipid content (Podemski \& Culp 2001) and ultimately stimulating their microbial degradation in the contaminated site (Stn A1).

We calculated the turnover rates of the main macromolecules as the ratio of enzymatically mobilised carbohydrates, lipids or proteins to the corresponding labile organic fraction. Values were expressed as days required for completing the turnover of each molecules' group. The Banduzzi Channel was characterised by the fastest turnover rates of both carbohydrates $(3.9$ d) and lipids (15.9 d), whereas an increasing gradient from the innermost station to the lagoon was observed for the Aussa River. These values further confirmed that the microbial benthic community at Stn A1 was more active than in the other studied areas. Protein turnover rates showed opposite dynamics, since the highest value was calculated in the Banduzzi Channel $(5.1 \mathrm{~d})$ and decreased along the Aussa River, indicating that the sediment of Stn A1 was characterised by a slower protein turnover, suggesting an accumulation of proteins. Nevertheless, the turnover of proteins was very fast compared with those calculated by Manini et al. (2003) in the Lesina and Marsala lagoons in winter (6 to 110 and 65 to $1464 \mathrm{~d}$, respectively) suggesting that the accumulation of proteins in the Banduzzi Channel was negligible. Turnover data confirmed the higher efficiency of benthic prokaryotes at Stn A1 in mobilising the organic matter pool. Prokaryote C 
conversion efficiency values provided more evidence of a well-developed microbial loop at Stn A1. At this site we detected the highest \% efficiency $(6.2 \%)$, whereas the other sites were characterised by decreasing values as proceeding upstream (at increasing LOM content). These results are in contrast to the findings of Danovaro \& Pusceddu (2007), who described increasing efficiency along with increasing LOM load. It must be noted, however, that our LOM data are generally higher than those used by Danovaro \& Pusceddu (2007) for their conceptual scheme and refer to lower efficiency. These results, coupled with previous findings, suggest that $\mathrm{C}$ conversion efficiency may be stimulated by higher LOM content up to a threshold value, after which the efficiency tends to decrease. An exception in this scheme would be provided by highly dynamic sites, such as those recovering from long-term pollution impacts (Stn A1).

Dissimilar environmental conditions such as grainsize and TOC content but especially increasing salinity from Stn A1 to Stn A4 selected different benthic assemblages and likely affected the benthic ecosystem functioning in the 4 studied sites. This was a descriptive study in which cause and effect relationships were not tested. Therefore, it was difficult to determine to what extent the differences among the benthic communities and their functioning were ascribable to synergistic effects of contaminants rather than to natural physical conditions occurring along a salinity gradient in a riverine-lagoonal system. However, at least in the severely impacted Stn A1, it is likely that a resistant though altered benthic community has been selected as a result of chronic perturbations that have occurred in the past few decades.

\section{CONCLUSIONS}

Looking at the macroscopic components of the benthic community, a low diversity system was observed in a contaminated site. However, when we focused on the microbial phototrophic community, in this site the highest richness was obtained. Primary producers sustained both higher trophic levels by direct input of biomass and microbial decomposers by input of labile carbon, which likely enhanced the degradation of refractory carbon via the process of microbial stimulation or co-metabolism. Even in a heavily contaminated site, high production and degradation rates were ensured by an extremely active microbial community.
Acknowledgements. This study was supported by the Special Commissioner for the socio-economic and environmental emergency in the Lagoon of Marano Lagunare and Grado. We are very grateful to Dr. G. Menchini for the contaminant data in the Banduzzi Channel. We thank Dr. C. Comici for TOC data, Dr. M. Lipizer for pigment analyses, Dr. A. Karuza for LOM analyses, Mr. M. Bussi for granulometric determination, and Dr. D. Deponte and Dr. R. Ramella for the use of the rubber boat. We are also grateful to Mr. Caressa who helped us during the sampling. A special thanks goes to Emilly Zhu for English style correction.

\section{LITERATURE CITED}

Alexander M (1982) Most probable number method for microbial populations. In: Page AL (ed) Methods of soil analysis, Part 2. American Society for Agronomy and Soil Science Society of America, Madison, WI, p 815-820

Berg P, Risgaard-Petersen N, Rysgaard S (1998) Interpretation of measured concentration profiles in sediment pore water. Limnol Oceanogr 43:1500-1510

> Blasutto O, Cibic T, De Vittor C, Fonda Umani S (2005) Microphytobenthic primary production and sedimentary carbohydrates along salinity gradients in the lagoons of Grado and Marano (Northern Adriatic Sea). Hydrobiologia 550:47-55

$>$ Bligh EG, Dyer W (1959) A rapid method for total lipid extraction and purification. Can J Biochem Physiol 37:911-917

Brambati A (1997) Metalli pesanti nelle lagune di Marano e Grado. Piano di studi finalizzato all'accertamento do sostanze persistenti nelle Lagune di Marano e Grado ed al loro risanamento. (RFVG) Direzione Regionale dell'Ambiente, Servizio dell'Idraulica, Trieste

Brambati A (2001) Coastal sediments and biota as indicators of $\mathrm{Hg}$ contamination in the Marano and Grado Lagoons. RMZ Mater Geoenviron 48:165-171

Burba N, Feoli E, Malaroda M (2008) MATEDIT: a software tool to integrate information in decision making processes. In: Neves R, Baretta JW, Mateus M (eds) Perspectives on integrated coastal zone management in South America. IST Press, Lisbon, p 123-127

> Bushnell LD, Haas HF (1941) The utilization of certain hydrocarbons by microorganisms. J Bacteriol 41:653-673

> Carman KR, Fleeger JW, Means JC, Pomarico SM, McMillin DJ (1995) Experimental investigation of the effects of polynuclear aromatic hydrocarbons on an estuarine sediment food web. Mar Environ Res 40:289-318

Carman KR, Means JC, Pomarico SC (1996) Response of sedimentary bacteria in a Louisiana salt marsh to contamination by diesel fuel. Aquat Microb Ecol 10:231-241

Carman KR, Bianchi TS, Kloep F (2000) Influence of grazing and nitrogen on benthic algal blooms in diesel fuelcontaminated saltmarsh sediments. Environ Sci Technol 34:107-111

Caumette P (1992) Bacterial communities in coastal lagoons. An overview. Vie Milieu 42:111-123

Christensen PB, Glud RN, Dalsgaard T, Gillespie P (2003) Impacts of longline mussel farming on oxygen and nitrogen dynamics and biological communities of coastal sediments. Aquaculture 218:567-588

Cibic T, Virgilio D (2010) Different fixatives and chloridric acid concentrations in microphytobenthic primary production estimates using radiolabeled carbon: their use and misuse. Limnol Oceanogr Methods 8:453-461 
Cibic T, Blasutto O, Falconi C, Fonda Umani S (2007a) Microphytobenthic biomass, species composition and nutrient availability in sublittoral sediments of the Gulf of Trieste (northern Adriatic Sea). Estuar Coast Shelf Sci 75:50-62

Cibic T, Blasutto O, Hancke K, Johnsen G (2007b) Microphytobenthic species composition, pigment concentration and primary production in sublittoral sediments of the Trondheimsfjord (Norway). J Phycol 43:1126-1137

Cibic T, Blasutto O, Burba N, Fonda Umani S (2008) Microphytobenthic primary production as ${ }^{14} \mathrm{C}$ uptake in sublittoral sediments of the Gulf of Trieste (northern Adriatic Sea): methodological aspects and data analyses. Estuar Coast Shelf Sci 77:113-122

Cibic T, Blasutto O, Bettoso N (2009) Microalgal-meiofaunal interactions in a sublittoral site of the Gulf of Trieste (northern Adriatic Sea, Italy): a three-year study. J Exp Mar Biol Ecol 370:144-154

Covelli S, Acquavita A, Piani R, Predonzani S, De Vittor C (2009) Recent contamination of mercury in an estuarine environment (Marano Lagoon, Northern Adriatic, Italy). Estuar Coast Shelf Sci 82:273-284

> Culp JM, Podemski CL, Cash KJ (2000) Interactive effects of nutrients and contaminants from pulp mill effluents on riverine benthos. J Aquat Ecosyst Stress Recov 8: $67-75$

Danovaro R, Pusceddu A (2007) Biodiversity and ecosystem functioning in coastal lagoons: Does microbial diversity play any role? Estuar Coast Shelf Sci 75:4-12

Danovaro R, Gambi C, Mirto S, Sandulli R, Cecchierelli VU (2004) Meiofauna. In: Gambi MC, Dappiano M (eds) Mediterranean marine benthos: a manual of methods for its samplings and study. Biol Mar Mediterr 11(Suppl 1): 55-97

> Danovaro R, Corinaldesi C, Filippini M, Fisher UR and others (2008) Viriobenthos in freshwater and marine sediments: a review. Freshw Biol 53:1186-1213

Deming JW, Barross JA (1993) The early diagenesis of organic matter: bacterial activity. In: Engel MH, Macko SA (eds) Organic geochemistry: principles and applications. Plenum Press, New York, NY, p 119-144

Dondi G, Marchini A, Sconfietti R (2003) La foce fluviale come gradiente d'ecotono: l'esempio del Fiume Natissa nel Nord-Adriatico. Stud Trentini Sci Nat Acta Biol 80: $237-244$

- Facca C, Sfriso A (2009) Phytoplankton in a transitional ecosystem of the Northern Adriatic Sea and its putative role as an indicator for water quality assessment. Mar Ecol 30:462-479

Falace A, Curiel D, Sfriso A (2009) Study of the macrophyte assemblages and application of phytobenthic indices to assess the ecological status of the Marano-Grado Lagoon (Italy). Mar Ecol 30:480-494

Fichez R (1991) Composition and fate of organic matter in submarine cave sediments; implications for the geochemical cycle of organic carbon. Oceanol Acta 14: 369-377

> Fleeger JW, Carman KR, Nisbet RM (2003) Indirect effects of contaminants in aquatic ecosystems. Sci Total Environ 317:207-233

> Gazeau F, Smith SV, Gentili B, Frankignoulle M, Gattuso JP (2004) The European coastal zone: characterization and first assessment of ecosystem metabolism. Estuar Coast Shelf Sci 60:673-694

- Goldfinch AC, Carman KR (2000) Chironomid grazing on benthic microalgae in a Louisiana salt marsh. Estuaries 23:536-547

Hartree EF (1972) Determination of proteins: a modification of the Lowry method that give a linear photometric response. Anal Biochem 48:422-427

Higgins RP, Thiel H (1988) Introduction to the study of meiofauna. Smithsonian Institution Press, London

Hoppe HG (1993) Use of fluorogenic model substrates for extracellular enzyme activity (EEA) measurement of bacteria. In: Kemp PF, Sherr BF, Sherr EB, Cole JJ (eds) Current methods in aquatic microbial ecology. CRC Press, Boca Raton, FL, p 423-431

Johnsen AR, Karen B, Ulrich K (2002) Detection of microbial growth on polycyclic aromatic hydrocarbons in microtiter plates by using the respiration indicator WST-1. Appl Environ Microbiol 68:2683-2689

> Larson F, Sundbäck K (2008) Role of microphytobenthos in recovery of functions in a shallow-water sediment system after hypoxic events. Mar Ecol Prog Ser 357:1-16

Lorenzen C, Jeffrey J (1980) Determination of chlorophyll in sea water. UNESCO Tech Pap Mar Sci 35:1-20

> Lunau M, Lemke A, Walther K, Martens-Habbena W, Simon M (2005) An improved method for counting bacteria from sediments and turbid environments by epifluorescence microscopy. Environ Microbiol 7:961-968

Lund HC, Lund JWG (1995) Freshwater algae. Biopress, Hong Kong

> Manini E, Fiordelmondo C, Gambi C, Pusceddu A, Danovaro R (2003) Benthic microbial loop functioning in coastal lagoons: a comparative approach. Oceanol Acta $26: 27-38$

Manini E, Luna GM, Danovaro R (2004) Benthic bacterial response to variable estuarine water inputs. FEMS Microbiol Ecol 50:185-194

Margalef R (1986) Ecologia. Omega, Barcelona

Morri C, Bellan-Santini D, Giaccone G, Bianchi CN (2004) Principles of bionomy: definition of assemblages and use of taxonomic descriptors (Macrobenthos). In: Gambi MC, Dappiano M (eds) Mediterranean marine benthos: a manual of methods for its samplings and study. Biol Mar Mediterr 11(Suppl 1):573-600

Mosetti F (1983) Sintesi sull'idrologia del Friuli-Venezia Giulia. Quad Ente Tutela Pesca 6:1-295

MPAAF (Ministero delle Politiche Agricole Alimentari e Forestali) (2002) Approvazione dei metodi ufficiali di analisi microbiologica del suolo. Decreto Ministeriale Agricoltura 8 luglio 2002, Rome

- Nieuwenhuize J, Maas YEM, Middelburg JJ (1994) Rapid analysis of organic carbon and nitrogen in particulate materials. Mar Chem 45:217-224

Nogales B, Lanfranconi MP, Piña-Villalonga JM, Bosch R (2011) Anthropogenic perturbations in marine microbial communities. FEMS Microbiol Rev 35:275-298

Paoli A, Celussi M, Valeri A, Larato C and others (2007) Picocyanobacteria in Adriatic transitional environments. Estuar Coast Shelf Sci 75:13-20

Pella E, Colombo B (1973) Study of carbon, hydrogen and nitrogen determination by combustion-gas chromatography. Mikrochim Acta 61:697-719

> Piani R, Covelli S, Biester H (2005) Mercury contamination in Marano Lagoon (Northern Adriatic Sea, Italy): source identification by analyses of $\mathrm{Hg}$ phases. Appl Geochem 20:1546-1559

Pielou EC (1966) Shannon's formula as a measure of species diversity: its use and misuse. Am Nat 100:463-465 
Pinder LCV (1986) Biology of freshwater Chironomidae. Annu Rev Entomol 31:1-23

Podemski CL, Culp JM (2001) Toxicant interactions with food algae: a missing link between laboratory and field effects? Environ Toxicol 16:31-42

Pusceddu A, Danovaro R (2009) Exergy, ecosystem functioning and efficiency in a coastal lagoon: the role of auxiliary energy. Estuar Coast Shelf Sci 84:227-236

Ravenschlag $\mathrm{K}$, Sahm $\mathrm{K}$, Knoblauch C, Jørgensen BB, Amann R (2000) Community structure, cellular rRNA content and activity of sulfate-reducing bacteria in marine Arctic sediments. Appl Environ Microbiol 66:3592-3602

Rees HL, Moore DC, Pearson TH, Elliot M, Service M, Pomfret J, Johnson D (1990) Procedures for the monitoring of marine benthic communities at UK sewage sludge disposal sites. Scottish Fisheries Information Pamphlet no. 18. Department of Agriculture and Fisheries for Scotland, Edinburgh

Revsbech NP (1989) An oxygen microelectrode with a guard cathode. Limnol Oceanogr 34:474-478

Round FE, Crawford RM, Mann DG (1992) The diatoms. Cambridge University Press, Cambridge

Sconfietti R, Marchini A (2001) The Stella River estuary in the Grado-Marano Lagoon: hard substrate community

Editorial responsibility: Katherine Richardson, Copenhagen, Denmark gradients. Atti Assoc Ital Oceanol Limnol 14:199-208

Sdrigotti E, Welker C (2002) The role of a macroalgal covering event on the microphytobenthos community in intertidal sediment (Marano Lagoon, northern Adriatic Sea). PSZN I: Mar Ecol 23(Suppl S1):370-383

Shannon CE, Weaver W (1949) The mathematical theory of communication. University of Illinois Press, Urbana, IL

Sharp JH (1974) Improved analysis for 'particulate' organic carbon and nitrogen from seawater. Limnol Oceanogr 19: 984-989

Shepard FP (1954) Nomenclature based on sand silt clay ratios. J Sediment Petrol 24:151-158

Simpson EH (1949) Measurement of diversity. Nature 163: 688

> Steemann-Nielsen E (1952) The use of radioactive carbon $\left({ }^{14} \mathrm{C}\right)$ for measuring organic production in the sea. J Cons Int Explor Mer 18:117-140

> Sundbäck K, Petersen DG, Dahllöf I, Larson F (2007) Combined nutrient-toxicant effects on a shallow-water marine sediment system: sensitivity and resilience of ecosystem functions. Mar Ecol Prog Ser 330:13-30

> Van Duyl FC, Kop AJ (1994) Bacterial production in North Sea sediments: clues to seasonal and spatial variations. Mar Biol 120:323-337

Submitted: October 7, 2011; Accepted: March 30, 2012 Proofs received from author(s): June 25, 2012 